"This is the peer reviewed version of the following article: Westley, Kieran \& McNeary, Rory (2014) Assessing the impact of coastal erosion on archaeological sites: a case study from Northern Ireland. Conservation and Management of Archaeological Sites 16(3): 185-211, which has been published in final form on Maney Online at http://dx.doi.org/10.1179/1350503315Z.00000000082."

\title{
Assessing the impact of coastal erosion on archaeological sites: a case study from Northern Ireland
}

Kieran Westley \& Rory McNeary (Centre for Maritime Archaeology, University of Ulster, Coleraine)

\begin{abstract}
This paper will present research on the vulnerability mapping of coastal archaeological sites currently being undertaken in Northern Ireland. The ultimate aim of this research is improve current predictions of where archaeological sites and landscapes will be at risk in the future from coastal erosion. The initial stage of this approach uses a suite of oblique aerial photographs to construct a baseline of eroding locations and coastal geomorphology. The erosion baseline can then be integrated with existing historic environment records to obtain a coarse first-pass archaeological vulnerability assessment. Subsequent stages can then use this assessment to prioritize future mitigation such as field surveys or monitoring exercises, or conduct further refinements of vulnerability classifications by incorporating information on site type and positioning on a local scale.
\end{abstract}

\section{Keywords}

Coastal erosion; vulnerability assessment; aerial photography, GIS, climate change 


\section{Introduction}

The destructive impact of coastal erosion on archaeological sites and monuments is a well-recognized and globally documented phenomenon (e.g. Carrasco et al., 2007; Fitzpatrick et al., 2006; Gibson, 2008; Jones et al., 2008). Today's heritage managers are also faced with the challenge that instances and rates of coastal erosion may increase with future climate change and sea-level rise (IPCC, 2007; Erlandson, 2008; Murphy et al., 2009). Key to effective management is to put in place now systems which can plan for this long-term threat rather than employing ad hoc or stop gap measures when it is too late. Consequently, over the last decade, there has been a proliferation of studies utilizing both desk- and field-based approaches to enhance records of coastal archaeological sites; identify areas of erosion; and estimate relative levels of site vulnerability (e.g. Dawson, 2003; Murphy et al., 2009; Westley et al., 2011; Daire et al., 2012; Reeder et al., 2012; Nitter et al., 2013).

The aim of this paper is to present the results of a recent study which seeks to assess the potential impact of coastal erosion on archaeological sites across the entire shoreline of Northern Ireland (a total distance of $c$. $850 \mathrm{~km}$ : Figure 1). This will be done using a uniform methodology based on analysis of oblique aerial photographs to facilitate direct comparison between individual sections of coastline. It is intended that the results will enable the local heritage agency (Northern Ireland Environment Agency (NIEA): Built Heritage division) to prioritize resources where they are most needed by identifying where erosion is most prevalent and where it will probably impact most on archaeological resources.

\section{Background}

In 2011, NIEA: Built Heritage commissioned the Centre for Maritime Archaeology (CMA), University of Ulster to produce a Northern Ireland-wide assessment of climate change impacts on archaeological heritage. A twophase approach was proposed with Phase 1 forming an overarching 'first-pass' strategic risk assessment conducted over two years (McNeary \& Westley, 2013). Phase 2, devoted to mitigation (e.g. survey, excavation, production of guidance and management strategies) would then be based on Phase 1's observations and conclusions. Such an approach was adopted because there are considerable knowledge gaps regarding potential climate change impacts on Northern Ireland's archaeological heritage (CCRA NI, 2012). Further, since this was the first time that such a project had been conducted in the province, it made sense to build it up from first principles and to capture the 'big picture' while at the same time going beyond generic predictions of climate impacts (e.g. CCRA NI, 2012) and producing data that is directly relevant to historic environment management. The research discussed in this paper comprises only on the coastal erosion component of Phase 1. The full assessment, including factors such as flooding (coastal and fluvial) and inland soil erosion, is discussed in McNeary \& Westley (2013). Given the desk-based nature of Phase 1, it was intended to draw on extant data, models or research on current and future patterns of coastal change. Therefore, the first step was to review existing work on coastal erosion in Northern Ireland to see if either comprehensive measurements of erosion existed, or if sufficiently detailed models were available which could be used as a basis for the archaeological vulnerability assessment. 


\section{Previous Research in Northern Ireland}

\section{Climate change}

Future climate change predictions for Northern Ireland have been modelled as part of the national risk assessment: the UK Climate Projections programme (UKCP09: Jenkins et al., 2009). From a coastal erosion standpoint, the key predictions concern sea-level rise (SLR) and storm frequency, as these are likely to result in increased rates and occurrences of erosion. SLR projections for Northern Ireland (relative to a 1980-99 baseline and adjusted for local land movements) indicate that a rise of $0.2-0.8 \mathrm{~m}$ is likely by $2090-2100$ with central estimates ranging between $0.3-0.4 \mathrm{~m}$ (Lowe et al., 2009) ${ }^{1}$. Changes in storm patterns are harder to predict, with no firm conclusions either way as to whether they will increase or decrease (Jenkins et al., 2009; NI CCRA, 2012). In short, there are valid reasons for assuming that coastal erosion in Northern Ireland will not decrease over the next century.

\section{Coastal erosion and archaeology}

Within the last five years, the survival and condition of archaeological sites in Northern Ireland has been assessed by the Condition and Management Survey of the Archaeological Resource (CAMSAR: Gormley et al., 2009). CAMSAR's key findings were based on a sample of 1500 sites (equivalent to c. $10 \%$ of the official Sites and Monuments Record (SMR) at the time of survey) and found that relatively few sites (7\%) were totally or substantially complete and that the most destructive factors were anthropogenic rather than natural (e.g. uncontrolled new built development, agricultural activities: see Gormley et al., 2009 for full discussion). This is supplemented by condition reports on the c. 2000 sites under statutory protection (State Care or Scheduled under the Historic Monuments and Archaeological Objects (NI) Order 1995) which are visited by Field Monument Wardens on a three to four year cycle (Foley, 2010).

However, these represent only a small part of the total record which currently encompasses over 26,000 sites if all Historic Environment Records (HERs) - consisting of the SMR, Industrial Heritage Record (IHR), Defence Heritage Record (DHR) and Register of Historic Parks and Gardens (HGR) - are amalgamated. Moreover, none of the above condition surveys focused explicitly on detecting and recording impacts which could be linked to climate change, though CAMSAR did suggest that it could adversely affect the archaeological resource in the future (Gormley et al., 2009). Consequently, prior to the research discussed in this paper, the impact of coastal erosion on archaeological sites in Northern Ireland was limited to anecdotal reports or a handful of published examples. For instance, rescue excavations of midden sites eroding out of sand cliffs fronting the Foyle estuary (Mallory \& Woodman, 1984; Mallory \& McCormick, 1988); the loss of an $18^{\text {th }}$ Century navigation pillar at Cloughy (McErlean et al., 2002) and episodic damage to a mid-19 ${ }^{\text {th }}$ Century pier at Ballyvoy (McErlean et al., 2011) and multi-period site at Dunnyneill (McCormick \& MacDonald, 2003).

\section{Coastal erosion}

A number of studies have demonstrated that coastal erosion is active in Northern Ireland. For example, Carter (1991) found that average erosion rates on soft coasts (i.e. beaches, dunes, estuaries) ranged between $<0.03-$

$2.56 \mathrm{~m} / \mathrm{yr}$ and inferred a general trend of slow recession. Erosion was linked not only to SLR but also to human action (e.g. sand extraction, construction of coastal structures: Carter \& Bartlett, 1990). Changes along hard, rocky coastlines were harder to detect and likely consisted of sporadic events rather than progressive change (McKenna et al., 1992). Greenwood \& Orford (2008), working within the semi-enclosed waterbody of Strangford Lough, measured erosion rates on unconsolidated cliffs of $<1-0.165 \mathrm{~m} / \mathrm{yr}$ with variations in rate linked to cliff height, angle and the local direction and magnitude of fetch.

Although the above studies clearly demonstrated and quantified coastal erosion, they have the drawback of not covering the entire province; a necessity when trying to develop a uniform, province-wide audit of heritage vulnerability. For example, the largest study (Carter, 1991) assessed only the north and north-east coast, while Greenwood \& Orford (2008) was restricted to Strangford Lough. The only available study that attempted to 
cover the entire coastline was the European-level 'Eurosion' project, an attempt to classify erosion on a continent-wide scale. However, this arguably lacks the resolution to be effective for heritage management and, in any case, has data gaps. For example, Larne and Strangford Loughs - both archaeologically significant areas do not appear to have been classified.

Another provincial-level study, this time examining general coastal vulnerability rather than erosion specifically, was McLaughlin (2001) (see also McLaughlin \& Cooper, 2010). This developed a Coastal Vulnerability Index (CVI): a model based on integration of the physical factors controlling vulnerability. Within the overall index were factors relating to erosion such as coastal topography, geomorphology and hydrodynamic conditions. From an archaeological perspective, this initially seemed a good basis for a vulnerability assessment given its province-wide coverage and resolution: down to $25 \mathrm{~m}$ for a regional (c. $10 \mathrm{~km}$ ) case study (McLaughlin \& Cooper, 2010). Moreover, CVI-based approaches for heritage management have been documented in the published literature (e.g. Reeder et al., 2012). However, it was subsequently found that only a low-resolution $(500 \mathrm{~m})$ study had been conducted at a provincial level; the high-resolution $(25 \mathrm{~m})$ version was limited to a single case study. In addition, the original CVI was created over a decade ago using datasets which were now outdated. Re-running it at an appropriate scale for archaeological analysis where sites tend to range from metres to several tens of meters in extent would require rebuilding it from scratch using updated baseline data. Updated values for some parameters, such as a high-resolution (10m) Digital Elevation Model (DEM), were easily obtained, but one crucial parameter - coastal landform - proved difficult as there was no digital province-wide record of coastal geomorphology. The need for a robust understanding of coastal geomorphology is conditioned by the fact that it exerts a strong control on how a given stretch of coastline responds to wave attack, tidal currents and storm events. It is therefore an essential component for assessing coastal erosion. In short, it was found that there was no extant up-to-date baseline assessment of coastal geomorphology which could be used to underpin the archaeological impact assessment, and therefore it would be necessary to create one.

Field visits to record landform/geomorphology type across the province were impossible within the project timescale and budget. Instead, extant suites of vertical and oblique aerial photographs (APs) were used to identify these coastal landforms. While this was underway, it was observed that coastal erosion (e.g. exposed vertical sections, unvegetated slopes, landslides) was actually visible on many of the oblique APs. Therefore, the strategy was altered so that the primary focus was to use the APs to create a baseline of observed erosion for the entire coast. This could then be compared directly with the HERs to form the basis for the initial province-wide coastal heritage impact assessment. Recording geomorphology was still retained as a secondary focus, to allow for construction of an updated CVI, should one be needed in the future.

\section{Methodology}

The methodology has three stages:

1) Assessing APs and mapping coastal erosion and geomorphology in a Geographical Information Systems (GIS) project.

2) Incorporating digital HERs into the GIS project, comparing them with the mapped erosion and using this to assess the vulnerability of archaeological/heritage sites.

3) Undertaking more detailed assessment of erosion patterns and site positions at a local (<several km) level.

Stages 1 and 2 were undertaken for the entire province. However, stage 3 was only done for two case studies to assess the efficacy of the approach. For analysis, the Northern Ireland coast was broken up into 10 regions each totalling between 32-164km long (Figure 1). 
Stage 1 used an extant series of oblique APs flown in 2006 by the Department of Environment Northern Ireland (DoENI). This comprises a continuous overlapping sequence of oblique APs spaced approximately $100-200 \mathrm{~m}$ apart along the entire coast and focussing directly on the coastline (Figure 2). All photographs are high resolution ( $4288 \times 2848$ pixels); however, clarity varies between individual frames depending on the distance from the camera to the shore and the ambient light on the day.

Individual oblique APs were opened in sequence and assessed for coastal geomorphology, erosion and the existence of coastal defences/man-made structures. For this exercise, erosion was defined as areas where active/recent sediment removal was clearly visible on the APs. These generally appeared as vertical or subvertical unvegetated scarps or sections, or unvegetated landslides. Degraded or currently vegetated scarps or landslides (indicating past erosion episodes) were not mapped. Each individual geomorphological landform (e.g. sandy beach, bedrock platform) was digitized into the GIS as a polygon layer overlaid on a basemap of vertical APs. Each polygon's position was based on common features visible in both the oblique and vertical APs (e.g. transitions in geomorphology, buildings, roads). The extent of erosion and presence of defences were then noted for each geomorphological landform. Finally, the erosion observations were cross-referenced with a point layer recording individual oblique AP positions. This was done to provide a simplified way of viewing the results, particularly at large spatial scales where the geomorphological polygons are almost invisible due to the narrowness of the coastal strip.

\section{Stage 2: Vulnerability Assessment of HERs}

The data layers created in Stage 1 were subsequently compared with extant HER databases to assess the vulnerability of archaeological sites to erosion. These included:

- Sites and Monuments Record (SMR): archaeological sites and historic monuments of all periods from the early Mesolithic (c. 9000 years ago) to the post-medieval and modern eras. Site types range from individual findspots to large earthworks, buildings and settlements. At the time of the assessment, the SMR contained 16,412 entries.

- Industrial Heritage Record (IHR): sites relating to the Industrial Revolution, a period of dramatic change from historical and social standpoints. A diverse array of 9,212 sites has been recorded including railways, mills, bridges, factories, ports and harbours.

- Defence Heritage Record (DHR): $20^{\text {th }}$ century sites built or utilized for military or defensive purposes, mainly during the first and second World Wars. The 434 recorded sites include air raid shelters, gun batteries, pillboxes, airfields and defensive structures.

- Register of Parks and Gardens (HGR): Ornamental parks and gardens constructed over the last three centuries. It presently contains 206 entries with sites ranging from small gardens $<0.5$ ha to large parks $>800 h a$ in size.

Assessment of vulnerability involved first filtering the HERs to extract all coastal sites. For this exercise, these were all sites seaward of, or within 150m inland of, the shoreline (as represented by the official Land \& Property Services (LPS) 1:50,000 shoreline shapefile). The coastal subset was filtered again to extract all sites seaward of, or within a) $150 \mathrm{~m}$ or b) $15 \mathrm{~m}$ inland of geomorphological polygons mapped as having visible erosion. The $150 \mathrm{~m}$ buffer is based on published erosion rates (Carter, 1991) which range from $<0.03-2.56 \mathrm{~m} / \mathrm{yr}$. Therefore, assuming a maximum of $2.56 \mathrm{~m} / \mathrm{yr}$; erosion over the next century would total $256 \mathrm{~m}$. Given that we are attempting to provide long-term insights into the state of the historic environment over the next 20-50 years, a figure of $150 \mathrm{~m}$ provides an appropriate maximum estimate (i.e. $256 \mathrm{~m}$ over 100 years equates to $128 \mathrm{~m}$ retreat in 50 years plus an additional buffer to account for errors in site positioning and digitizing to give a final total of $150 \mathrm{~m}$ ). We note that the value of $2.56 \mathrm{~m} / \mathrm{yr}$ is a maximum estimate from the published literature, and 
other studies have measured much lower rates (e.g. Greenwood \& Orford, 2008). Therefore the 150m buffer represents an absolute maximum for the next half century.

Repetition of the process using a $15 \mathrm{~m}$ buffer is intended to highlight the number of sites that will be at risk in the next 5 years (i.e. 5 years of erosion at $2.5 \mathrm{~m} / \mathrm{yr}=12.5 \mathrm{~m}$, plus an additional buffer for errors in site positioning and digitizing giving a final total of $15 \mathrm{~m}$ ). In addition, a distance of $15 \mathrm{~m}$ also equates to 50 years of erosion at $0.3 \mathrm{~m} / \mathrm{yr}$. This value is close to the average erosion rates from Carter (1991) $(0.36 \mathrm{~m} / \mathrm{yr}$ to be precise). Therefore, in addition to functioning as a maximum estimate for the next 5 years, the $15 \mathrm{~m}$ buffer is also an intermediate, and perhaps more realistic, estimate of vulnerability over the coming 50 years.

We recognize that erosion rates are highly variable around the Northern Ireland coast (e.g. Carter, 1991; Greenwood \& Orford, 2007) and that the use of generic buffers masks local variation and its corresponding impact on archaeological sites. However, in the absence of accurate measured erosion rates from all around the coast, the best that can be done on a provincial-scale is to use the extant historic rates to define buffers of potential impact. In any case, once the geomorphological/erosion and HER data are incorporated into the GIS, it is relatively simple to re-run the buffer classification with different values, for example generated from more accurate erosion measurements, if these become available.

\section{Stage 3: Local case studies}

In this stage, the filtered subset from $150 \mathrm{~m}$ buffer (i.e. the maximum number of sites at potentially at risk) was examined in greater detail. The key difference compared to the province-wide assessment (stages 1 and 2 ) is that Stage 3 utilized a smaller scale of analysis and a greater degree of interpretation. Effectively, it refined the buffer-generated results by examining the position of each site, its nature and the local patterns of erosion and/or geomorphology.

\section{Results}

This paper will only provide 2 case studies (South Down and Larne Lough; for full results see McNeary \& Westley, 2013). However, the final discussion and conclusion will involve results from all regions.

\section{South Down Stage 1}

This area is located between Warrenpoint and Newcastle, is approximately $85 \mathrm{~km}$ long and includes the sheltered embayment of Carlingford Lough and the exposed Irish Sea-facing coast of south County Down (Figure 3). At Warrenpoint, a defended harbour forms the shoreline before giving way to beaches (predominantly sand/gravel, and some of which are backed by coastal defences) interspersed with small intertidal flats and occasional bedrock outcrops. A large $(c .3 \times 2.5 \mathrm{~km})$ expanse of intertidal mudflat occurs at Mill Bay where it forms a pronounced indentation in an otherwise linear shoreline. These mudflats lack visible coastal defences. From Mill Bay until Cranfield Point, the coast consists of a sand beach backed by a low scarp. No erosion is visible here barring isolated spots, such as behind the beaches at the Lough entrance. Erosion is evident on the eastern side of Cranfield Point and southwestern tip, but the rest of it is protected by a seawall (Figure 3A).

Cranfield Point forms a cliff of unconsolidated glacially-derived gravel and sand up to $15 \mathrm{~m}$ high and is generally fronted by a sandy beach. The cliff-beach complex continue largely unbroken for c.12km with the exception of Kilkeel (a small harbour) and Maghereagh, where the cliff runs inland leaving a low scarp backing the beach. Coastal defences are discontinuous along this stretch; large expanses (e.g. Derryoge) are undefended, while isolated areas, particularly around caravan parks and houses, have rock armour. Erosion is obvious, particularly between Derryoge and Kilkeel, where a continuous segment of the cliff has unvegetated sections with neartotal exposure of their constituent sediments (Figure 3B). At least seven collapses can also be seen along this cliffline alone. At Kilkeel, erosion has been prevented by concreting the cliff to protect the coastal road. Note 
however, that there appears to be minimal erosion between Cranfield Point and Derryoge because the cliff is set further back from the active shoreline than the eroding section between Derryoge and Kilkeel. The vulnerable unconsolidated cliff also runs north of Kilkeel, and consequently, erosion is also visible here (Figure 3C). However, the exposed sections tend to be shorter and smaller with the majority of the cliff face remaining vegetated.

At Ballymartin, the cliff-beach complex is replaced by a series of bedrock platforms/boulders, continuing largely unbroken up the coast with the exception of Annalong harbour. Erosion is restricted to isolated spots on the unconsolidated terrestrial sediment backing the resistant rock platforms creating low vertical exposures (Figure 3D). The unconsolidated cliff and beach returns north of Annalong (Glasdrumman townland), now reaching heights of up to $25 \mathrm{~m}$. The cliff continues past Ballaghanery Upper, but is now composed of bedrock and the beach is replaced by bedrock platforms. The rocky substrate means that erosion concentrates in narrow vertical faces at the cliff top where unconsolidated sediment sits atop the bedrock.

\section{South Down Stage 2}

There are forty-nine coastal historic sites recorded within the HERs. Sites are unevenly distributed with the majority clustering within Carlingford Lough and around Cranfield Point. Sites are relatively sparse along the Irish Sea coast, with small concentrations around Kilkeel and Annalong. This number reduces to twenty-two and eighteen sites for those seaward of the shoreline or within 150 and $15 \mathrm{~m}$ of eroding areas respectively (Figure 4). Filtering the sites by eroding areas reduces the numbers of sites within Carlingford Lough, a product of the extensive shore defences and minimal visible erosion. The largest cluster of sites remains at Cranfield Point, largely due to the existence of offshore/intertidal features such as navigation markers and smaller groupings around Kilkeel and Annalong.

\section{South Down Stage 3}

For the local-level assessment, a 13km stretch between Mill Bay and Kilkeel was examined. This encompasses the intertidal flat at Mill Bay and the cliffs and beaches between Cranfield Point and Derryoge. According to Stage 2, there twenty-one HER (13 IHR, 1 DHR, $7 \mathrm{SMR}$ ) sites situated seaward of, or within 150m of the shoreline. Of these, sixteen (10 IHR, 1 DHR, 5 SMR) are identified as being seaward of the shoreline or within $150 \mathrm{~m}$ of an area with visible erosion.

Closer inspection of each of the sixteen reveals the following (Table 1 \& Figure 5). Of the ten IHR sites, six are situated in defended areas, and therefore at low risk from erosion. One site appears to have been recorded incorrectly: 03636 is recorded as a coastguard station/lightkeeper's dwelling but has been positioned within an offshore tidal channel. Without an accurate location, a judgment cannot be made as to its vulnerability. Three sites (03637, 03638: beacons; 03642: lighthouse) are offshore and could be at risk from erosion or storm damage. However, this is mitigated because they were designed for such eventualities, and their resistance is therefore a function of their structural integrity as much as future climate change. The single DHR site (440: bomb store) is approximately $80 \mathrm{~m}$ inland of an unconsolidated cliff with visible erosion. It is therefore not at immediate risk, but could be in the future, should cliff retreat continue or accelerate.

Of the five SMR sites, two (DOW57:001: motte; DOW57:009: mound) are far enough (60 and 110m respectively) from the shoreline that erosion is not an immediate threat. In the long-term however, DOW057:001 is regarded as being at greater risk because the adjacent shoreline is undefended. The remaining three sites are at high risk from erosion. DOW057:010 (artillery fort) is located on a rock in Carlingford Lough and therefore highly exposed to storms and waves. Indeed, its SMR entry reports that it has already suffered storm damage. DOW057:11 (shell midden) is located on the eroding face of Cranfield Point. Loose material, such as middens and lithic scatters, in unconsolidated deposits are particularly vulnerable as they are more easily disturbed than built structures. Its SMR entry is also uncertain as to whether the midden still exists or has already eroded away. Finally, DOW057:17 (burials) is located only a few metres from the shoreline. Although 
this is not visibly eroding, it is undefended and composed of unconsolidated sediments which are prone to erosion, as shown by localized exposures in similar landforms further up the coast.

There are also unrecorded sites at risk. Firstly, a visit to Derryoge in 2011 confirmed that several stone buildings are perched on, or just below, the eroding cliff edge and have collapsed as the underlying cliff has retreated. These buildings are visible on the oblique APs (Figure 6) and also mapped on the First and Second Edition County Series ( 6 Inch) maps, making them at least $19^{\text {th }}$ century in age. Secondly, an extensive set of kelp grids can be seen on the intertidal flats of Mill Bay. Although noted in the published literature (McErlean, 2007), they are not recorded in the HERs. Whether or not they will suffer erosion in the future is uncertain. Their surrounding environment - a low energy intertidal flat - would suggest that erosion is unlikely, or perhaps that silting up could be a greater possibility. However, without further research, it is not possible to say for certain.

\section{Larne Stage 1}

This area is located in County Antrim between Blackhead and Drains Bay, is approximately $61 \mathrm{~km}$ long and encompasses the Irish Sea coast of Islandmagee and the sheltered water of Larne Lough (Figure 7). South of Blackhead, the coastline consists of an unconsolidated, coarse-grained beach (primarily gravel/boulder but with some sand). Erosion is present in the form of exposed vertical scarps, sometimes several metres high, cut into the unconsolidated slopes behind the beach (Figure 7A). Topography then rises sharply to form basalt cliffs $>25 \mathrm{~m}$ high at Blackhead. These run north for a short distance before sloping down to allow coarse-grained (sand, gravel or boulder) beaches to form. These continue for c. $3 \mathrm{~km}$ whereupon, at Gransha, sheer $25 \mathrm{~m}$ high bedrock cliffs return. These run largely unbroken for the majority of Islandmagee's eastern coastline and have no visible erosion.

South of the Isle of Muck, topography becomes gentler and coarse-grained beaches and bedrock platforms appear. The Isle of Muck is a good example of how coastal geomorphology is dependent on exposure: its outereast facing coast is a bedrock cliff, while its inner, more sheltered shoreline has coarse grained beaches. North of Portmuck, the coast exhibits a mix of high energy features including bedrock cliffs, platforms and boulder and gravel beaches. The exceptions are the two bays on the tip of Islandmagee where greater shelter and lowlying topography allow the formation of sand beaches. Around the top of the peninsula, a few isolated exposures are visible behind boulder beaches and low platforms.

At the eastern side of Larne Lough's entrance, the coast consists initially of bedrock platforms which give way to partly defended sand/gravel beaches, often with boulders. These beaches form a continuous fringe down the Lough's north-eastern shore until an intertidal flat at Mill Bay. Visible erosion is minimal, presumably resulting from the shallow bathymetry and sheltered conditions. Small isolated exposures occur as far down as Kilcoan Beg. Around Mill Bay these breaks occur in walls or structures along the shore. The headland south of Mill Bay then consists of an unconsolidated beach which in turn gives way to an intertidal flat. From here to the southern end of the Lough, the shoreline consists almost entirely of intertidal flat, with marsh concentrated at the southernmost margin. Two longer sections of possible erosion were identified between Kilcoan Beg and the southern end of the Lough. These were picked out on the basis of distinct vertical edges visible along the fringe of marsh vegetation (Figure 7B). Note however, that there are uncertainties associated with this attribution, for instance whether this is the natural appearance of the marsh or indicative of active retreat.

The southwestern Lough shore also consists of intertidal flat, although some sections are cut by railway embankments. Potential eroding areas consist again of vertical edges to marsh vegetation. Some of these are fronted by an apparently bouldery substrate which could indicate an erosion surface. The flats are replaced by sand/gravel beaches around the Magheramorne Quarry. Thereafter; erosion is characterized by low vertical scarps, occasionally with collapses, backing the beach (Figure 7C). These are interspersed with long sections of defended embankments. From here until Larne, the shoreline is heavily modified with extensive seawalls and 
railway embankments. Natural features are restricted to short stretches of intertidal flat and unconsolidated beach. The southern and eastern margins of Larne itself are entirely defended by seawalls and harbour facilities and hence erosion-free, the exception being the Curran Point, where sand/gravel beaches are still present together with some isolated unvegetated exposures.

North of Larne, the coastline becomes more open, initially with sand/gravel beaches and short stretches of platforms and boulders which gradually become more prevalent. This section is undefended with the exception of structures south of Blackhead and immediately north of Larne where they protect the coastal road and housing. Consequently, erosion is visible between Larne and Drains Bay in the form of low scarps apparently retreating back from beaches or platforms (Figure 7D).

\section{Larne Stage 2}

There are eighty-three coastal historic sites recorded within the various HERs. Sites are spread across the study area, though there are large gaps on the Islandmagee cliffs and a dense cluster at Larne itself and the Lough entrance. These numbers reduce to sixty-one and thirty-five sites if filtered to seaward of the shoreline or within 150 and $15 \mathrm{~m}$ of eroding areas respectively (Figure 8 ). In both cases, sites are distributed within the Lough as well as on the open Islandmagee coast.

\section{Larne Stage 3}

For the local-level case study, an $11 \mathrm{~km}$ stretch between Blackhead and Portmuck was examined. This encompasses the unconsolidated beaches south of Blackhead, the bedrock cliffs of eastern Islandmagee, bedrock platforms around Portmuck and the Isle of Muck. Despite high wave exposure, the oblique APs suggest that erosion is limited to southernmost part of the shoreline between Blackhead and Gransha townland. This relates principally to the fact that the unconsolidated slope deposits are more susceptible to erosion than the solid bedrock cliff further north.

According to Stage 2, there twenty-four (13 IHR, 11 SMR) coastal historic sites, of which nineteen (11 IHR, 8 SMR) are identified seaward of the shoreline or within $150 \mathrm{~m}$ of an eroding area (Table 2 \& Figure 9 ). Of the IHR sites, ten are regarded as moderate risk, either because they are situated on defended or rocky shorelines (06998: harbour; 07001: port; 07147: boat port), because they consist of structures designed for use in the sea (06989: concrete pier) or because they could be utilized natural features rather than built structures. This is exemplified by several boat port/harbour sites $(07139-07143,07145)$. Although situated right on the shoreline in an area with identified erosion, they are classified as moderately vulnerable because there are no visible remains and the sites could simply be natural landing places rather than artificial harbours. The exception to this is 07144 (Marchburn Port) which has a visible artificial channel and is therefore classified as highly vulnerable.

Of the SMR sites, one (ANT041:023: wall) is classified as high risk, despite its location on a shoreline with no mapped erosion. This is due firstly to its proximity $(<5 \mathrm{~m})$ to the water's edge, and the fact that it is collapsing, as seen in the oblique APs and also recorded in the SMR entry. Three sites are regarded as moderate risk, all for slightly different reasons. ANT047:029 (church site) is c. 20-30m upslope from an eroding shoreline. It is therefore not at immediate risk, but could be in the long term. ANT037:032 (boulder) is situated at high water mark on an unconsolidated shoreline. However, the actual monument is a $5 \mathrm{~m}$-wide natural boulder which is expected to have some resistance to erosion. ANT041:037 (skeleton) is an isolated findspot at the foot of a resistant bedrock cliff. However, it is only a metre above high water. Therefore, if any associated remains are left, they could be vulnerable to storm waves. Two SMR sites are regarded as low risk (ANT041:002: mound; ANT41:013: rath) as they are situated inland of resistant bedrock cliffs. Note also that ANT041:013 was recorded as unlocated, but is visible in the oblique APs. Two additional SMR sites are unlocated (ANT041:024: well; ANT41:029: standing stones) or appear to be positioned incorrectly (e.g. ANT041:024 is mapped as offshore). Their risk level is therefore unknown. 


\section{Discussion}

\section{Province-wide assessment}

In total, 7157 oblique APs covering c. $850 \mathrm{~km}$ of shoreline were examined. Of these, 1089 (15.2\%) had evidence of erosion (summary in Table 3). This is a crude estimate of erosion magnitude for two reasons. Firstly, the area covered by individual APs varies depending on the local shoreline configuration (e.g. linear versus indented) and distance between the camera and the shore. Consequently, individual study areas were covered by between 5.6-12.5 APs per kilometre of shoreline. Secondly, the APs provide only a snapshot in time, and thus do not indicate whether erosion is actively progressing or not. Thus, some of the areas identified as eroding could actually be presently stable (though their categorization as eroding implies that they have at least the potential for erosion). Finally, there are uncertainties in the attribution of erosion to particular features, such as marsh edges; and where interpretation was hindered by poor AP quality. Nonetheless, this assessment at least gives a first pass overview which, crucially, has been conducted using a consistent methodology for the entire province. In addition, the figure of $15.2 \%$ is at least in the same ballpark as the figure of $20 \%$ (of the total coastline experiencing erosion) quoted in the official documentation (NI CCRA, 2012; Masselink \& Russell, 2008) giving a degree of confidence that it is broadly representative.

Therefore, if AP erosion percentage is used as a crude proxy, it can be applied to each of the study areas to compare their relative risk levels (Figure 10 and Table 3 ). This implies that the Foyle area is most at risk with almost $29 \%$ of its APs showing erosion. The next highest percentages cluster between $17-18 \%$ and include the Outer Ards, Larne, East Antrim and the North Coast. The majority of shorelines in these areas, excepting small semi-enclosed embayments (Bann Estuary, Larne Lough), are highly exposed and would be expected to have relatively high erosion rates. The remaining areas - South Down, Southeast Down, Strangford Lough, Belfast Lough and Rathlin all have percentages between $8-15 \%$. Of these, only Belfast has a percentage below $10 \%$. The results for Belfast, Strangford and Rathlin are the least surprising and most explicable. Belfast's low value stems from extensive shore defences lining the Lough. Strangford Lough is the most sheltered of all the study areas, with no exposure to the open sea and limited fetch. Rathlin, despite its highly exposed situation, is dominated by resistant bedrock cliffs and platforms. The values for South and Southeast Down however, are more surprising because it might be expected that, given their exposed situation, frequency of unconsolidated sediments close to the shoreline and visibly eroding sections, they would have higher levels of erosion. In reality, this study suggests that while there are distinct high risk localities within each area (e.g. Derryoge), the majority of the shoreline is not visibly eroding.

In total, 1716 coastal sites were filtered out of the HER databases. Of these, 1161 (67.7\%) and 879 (51.2\%) were situated seaward of the shoreline or within $150 \mathrm{~m}$ or $15 \mathrm{~m}$ of an eroding area respectively. In comparison with the total number of HER sites across the entire province $(26,264)$, these equate respectively to $4.4 \%$ and $3.3 \%$ of the total extant record (Table 3). When broken down regionally, the following pattern emerges. Strangford Lough and Rathlin Island are ranked as the most vulnerable areas when using both the $150 \mathrm{~m}$ and $15 \mathrm{~m}$ buffers. However, this contrasts with their relatively low incidence of recorded erosion (eight and seventh place respectively). The high site vulnerability ranking is driven mainly by the sheer number of recorded coastal and intertidal sites in the two areas, a product of intensive archaeological surveys (McErlean et al., 2002; Forsythe \& McConkey, 2012) which have not been undertaken in the other study areas. At the other end of the scale is South Down, which has fewer than twenty-three sites at risk under both $150 \mathrm{~m}$ and $15 \mathrm{~m}$ buffers. The study areas in between cluster relatively closely so that, in terms of site numbers, no more than twelve and five sites separate individual ranking positions for the $150 \mathrm{~m}$ and $15 \mathrm{~m}$ buffers respectively.

If we accept that using numbers of sites alone is flawed in that not all areas have been subject to the same level of survey, then the alternative is to use percentages of sites at risk. This will at least give an idea of the 
proportion of sites at risk from the total record regardless of whether it is the product of a intensive survey or not. However, as before, the data still suggest that the most vulnerable area is Strangford Lough. This is less down to the overall high numbers of sites, but the fact that the vast majority of the record reflects past maritime activity and is thus situated in the intertidal zone or close to the shoreline. Rathlin however, is now ranked much lower; seventh and fifth respectively for the $150 \mathrm{~m}$ and $15 \mathrm{~m}$ buffers. Thus, while Rathlin has been a focus of maritime activity, with many recorded coastal sites, the island's resistant geomorphology means that a greater proportion of sites are not at risk. The area with the lowest proportion of sites at risk is Belfast Lough and reflects the fact that it is heavily defended. Therefore, while it has a sizeable coastal record (third after Strangford and Rathlin), far fewer of its sites are at risk.

There are advantages with the method used, principally its uniform coverage of the coastline and rapidity (e.g. coastline lengths of $20-30 \mathrm{~km}$ were regularly assessed per working day). However, there are also some limitations (see also Morgan et al., 2011 for additional discussion on using oblique APs for geomorphological research). Firstly, the APs were flown in 2006. Therefore, the resulting baseline is effectively 6-7 years out of date. Observed eroding areas could now be re-vegetated, new eroding areas could be exposed or new defences constructed. Also, they represent a snapshot of the coastline at a single point in time when in fact, some areas are known to experience periodic erosion and then accretion on a seasonal basis (Cooper, 2010). Secondly, while the overall AP quality was good, on occasions it was poor enough that it was difficult to conclusively identify erosion. In other instances, the critical part of the coastline was obscured, for example, by washed-up kelp. Nonetheless, it was felt that there were sufficient clear APs to provide a representative result and, short of conducting an entirely new coastal survey, this was the best that could be accomplished with the available data. However, given the limitations, the results should be treated only as a first-pass strategic overview which examines relative risk levels across the province.

Local-scale assessment

The obvious difference between local-scale and province-wide assessments is that the former allows a more detailed assessment of vulnerability, down to a site level. This allows assignation of more appropriate risk levels based on the site/monument type and its position in relation to local erosion and shore defences. With respect to site/monument type, those located in the offshore and intertidal zones might be expected to have high risk levels owing to exposure to waves, tides and storms. However, many of them are structures designed for such eventualities and therefore, if properly maintained, should have some resistance. A good example is the Haulbowline Lighthouse (IHR03642), which has been classified as moderate risk despite its exposed position at Carlingford Lough's entrance. Alternatively, as shown in the Eastern Islandmagee example, some recorded sites, particularly landing places, may simply be utilized natural features and can be assigned lower levels of vulnerability.

Regarding site locations, a key observation is that reported positions within the HERs can be incorrect. Simple errors in data entry, the use of single datum points for large sites, unlocated sites described from historic sources or even use of shortened grid references are all contributory factors. This is shown by three sites in the above case studies with unknown levels of vulnerability because the precise locations are not known. Even minor errors in positioning (e.g. several metres to low tens of metres) can affect classifications by placing sites on either side of the shoreline or just inside/outside the buffers used to determine proximity to erosion (see also Westley et al., 2011). An example of this is ANT041:23 (a wall) which was included within the local-scale analysis because it was mapped as seaward of the shoreline. However, the APs actually show that it is above high water. Moreover, although erosion on the shoreline itself was not apparent from the APs, both the SMR entry and APs indicate that it is collapsing. Consequently, it has been classified as highly vulnerable.

Overall, these two small case studies highlight the fact that the most accurate historic environment vulnerability assessments will require the background on each coastal site to be examined in order to verify its position and nature and produce appropriate estimates of vulnerability. The drawback is that it is much more 
time consuming to proceed on a site-by-site basis than the buffer-driven method of the province-wide overview. Moreover, even in the local-scale assessments, there are still uncertainties, particularly with respect to modelling future change. In the examples above, sites inland but within a few tens of metres of an eroding/potentially eroding shoreline were simply classified as having moderate vulnerability. The reality is that without precise estimates of local erosion rates, it is not possible to predict when these sites will actually be threatened. That said, even a simple local-scale exercise can be used as a follow-up to the strategic overview, targeting areas that are identified as especially vulnerable.

\section{Conclusion}

This is the first attempt to conduct a vulnerability assessment of Northern Ireland's coastal historic environment. It was conducted using extant APs to characterize coastal geomorphology and identify zones of erosion which, when combined with HER records, have been used estimate relative levels of archaeological site vulnerability. The main conclusions of the province-wide assessment are:

- Coastal erosion, or at the very least, apparent erosion, occurs across c. $15 \%$ of the Northern Ireland shoreline on the basis of a crude proxy (percentage of APs showing erosion).

- Long (i.e. $>100 \mathrm{~m}$ ) continuous sections of erosion are relatively rare and most visible erosion occurs in localized intermittent sections that are metres to low tens of metres long.

- The study areas at greatest and least risk respectively are the Foyle and Belfast Lough. The remaining areas cluster in between with little difference separating individual ranking positions.

- Areas identified as particularly vulnerable from a historic environment perspective in the immediate term (\% sites $<15 \mathrm{~m}$ from eroding areas) include Strangford Lough and the Foyle. The least vulnerable are Belfast Lough and East Antrim. The remaining areas cluster in between with little difference separating individual ranking positions.

- Areas identified as particularly vulnerable from a historic environment perspective in the long term (\% sites $<150 \mathrm{~m}$ from eroding areas) include Strangford Lough, Larne, Outer Ards and the Foyle. The least vulnerable is Belfast Lough. The remaining areas cluster in between with little difference separating individual ranking positions.

- Coastal erosion represents a long-term threat to the historic environment. Although the overall vulnerable proportion of the historic environment is estimated as being relatively small ( $4.4 \%$ and $3.3 \%$ over the next 50 or 5 years respectively assuming a worst case erosion scenario, or $3.3 \%$ over the next 50 years assuming a intermediate scenario), this still represents several hundred sites. Moreover, these represent only the known record. The number of vulnerable sites could increase with new discoveries, such as are often revealed in new exposures.

Going beyond these wide-ranging conclusions to the level of specific sites requires a more detailed local-scale analysis. The examples presented here found that:

- More appropriate vulnerability classifications can be generated for individual sites based on their nature (e.g. concrete structure vs. loose material in section) and location.

- Recorded positions in the HERs are sometimes inaccurate and affect vulnerability classifications.

- Assessing vulnerability levels for sites at, or close to, the active shoreline is relatively straightforward but doing so for sites further inland is more difficult. Specific predictions of future impacts would require similarly accurate estimates of local erosion which presently do not exist for many areas.

- While effective, the local-scale approach is time-consuming and best used as a targeted follow-up to the strategic overview.

This study also more generally has provided an example of a rapidly undertaken coastal assessment which can be used for archaeological/heritage management purposes. We recognize that not all places will have the same 
level of AP coverage, nor will the technique ever be as accurate as field-based coastal surveys or provide the quantified measurements generated by dedicated erosion monitoring exercises. We also recognize that additional field-based ground-truthing, for instance through prioritized coastal surveys, is needed to robustly test its validity. Nonetheless, we hope it will prove useful as a first-pass assessment to enable managers to get over the initial hurdle of dealing with coastal erosion and climate change and to form the basis for targeted action. For Northern Ireland specifically, the aspiration is that it will be followed by such work; and ultimately will help secure the future of our valuable coastal heritage.

\section{Acknowledgements}

This work was funded by the Northern Ireland Environment Agency, and carried out at the Centre for Maritime Archaeology, University of Ulster. We would like to express our thanks to colleagues at both institutions for their advice and support; in particular Rhonda Robinson, John O'Keefe, Colin Breen, Tom McErlean \& Brian Williams. We are also grateful to Prof. Andrew Cooper for his insightful comments on the manuscript. All map data used for this study is from Land \& Property Services and was supplied to the University of Ulster under the Northern Ireland Mapping Agreement. All HER datasets were provided courtesy of NIEA: Built Heritage division.

\section{Footnotes}

${ }^{1}$ Numerical predictions, maps and graphs are accessible via the online UKCP09 user interface data portal: http://ukclimateprojectionsui.defra.gov.uk/ui/start/start.php

${ }^{2}$ See Eurosion website at: http://www.eurosion.org/

\section{References}

Carrasco, A., Ferreira, O., Matias, A. \& Dias, J. 2007. Historic monuments threatened by coastal hazards at Boca do Rio, Algarve, Portugal. Coastal Management, 35(2):163-79.

Carter, R.W.G. \& Bartlett, D. 1990. Coastal erosion in Northeast Ireland - Part I: Sand beaches, dunes and river mouths. Irish Geography, 23:1-16.

Carter, R.W.G. 1991. Shifting Sands. A study of the coast of Northern Ireland from Magilligan to Larne. Belfast: HMSO. CCRA NI 2012. A Climate Change Risk Assessment for Northern Ireland. [Accesed 21 January 2012]. Available at: http://www.defra.gov.uk/environment/climate/government>

Cooper, J.A.G. 2010. Northern Ireland. In: Bird, E.C.F. (ed) Encyclopaedia of the World's Coastal Landforms. Pp. $536-544$. Berlin: Springer-Verlag.

Daire, M-Y., Lopez-Romero, E., Proust, J-N., Regnauld, H., Pian, S. \& Shi B. 2012. Coastal Changes and Cultural Heritage (1): Assessment of the Vulnerability of the Coastal Heritage in Western France. Journal of Island and Coastal Archaeology, 7:2, 168-82.

Dawson, T. ed. 2003. Coastal archaeology and erosion in Scotland. Edinburgh: Historic Scotland.

Erlandson, J. M. 2008. Racing a rising tide: global warming, rising seas and the erosion of human history. Journal of Island and Coastal Archaeology, 3(2):167-69.

Fitzpatrick, S., Kappers. M \& Kaye, Q. 2006. Coastal erosion and site destruction on Carriacou, West Indies. Journal of Field Archaeology, 31(3):251-61. 
Foley, C. 2010. Field Monument Wardens in Northern Ireland: working with owners to manage scheduled historic monuments. In S. Trow, V. Holyoak and E. Byrnes, eds. Heritage Management of Farmed and Forested Landscapes in Europe. EAC occasional paper 4:87-9.

Forsythe, W. \& McConkey, R. 2012. Rathlin Island. An archaeological survey of a maritime landscape. Belfast: TSO

Gibson, J. 2008. Rising tides. The loss of coastal heritage in Orkney. Orkney: Northings

Gormley, S., Donnelly, C., Hartwell, B. \& Bell, J. 2009. CAMSAR: A Condition and Management Survey of the Archaeological Resource in Northern Ireland. Belfast: TSO.

Greenwood R. \& Orford, J. 2008. Factors controlling the retreat of drumlin coastal cliffs in a low energy marine environment - Strangford Lough, Northern Ireland. Journal of Coastal Research, 23(2):285-97.

IPCC. 2007. Climate change 2007. Synthesis Report. Contribution of Working Groups I, II and III to the Fourth Assessment Report of the IPCC. Geneva: IPCC

Jenkins G., Perry, M. \& Prior, M. 2009. The climate of the United Kingdom and recent trends. Exeter: Met Office Hadley Centre.

Jones, B., Hinkel, K., Arp, C. \& Eisner, W. 2008. Modern erosion rates and loss of coastal features and sites, Beaufort Sea coastline, Alaska. Arctic, 61:361-72.

Lowe, J., Howard, T., Pardaens, A., Tinker, J., Holt, J., Wakelin, S. \& others. 2009. UK Climate Projections science report: Marine and coastal projections. Exeter: Met Office Hadley Centre.

Mallory, J.P. \& Woodman, P.C. 1984. Oughtymore: An Early Christian shell midden. Ulster Journal of Archaeology, 47:5162.

Mallory, J.P. \& McCormick, F. 1988. Excavations at Ballymulholland, Magilligan Foreland, Co. Londonderry. Ulster Journal of Archaeology, 51:103-114.

Masselink, G. \& Russell, P. 2008. Coastal erosion and coastal geomorphology. In MCCIP Annual Report Card 2007-2008 Scientific Review. [Accessed 3 December 2009]. Available at: http://www.mccip.org.uk/annual-report-card/20072008/marine-environment/coastal-erosion.aspx

McCormick, F. \& MacDonald, P. 2003. Data Structure Report: Dunnyneill Islands, County Down 2002 and 2003. Report prepared for the Environment \& Heritage Service, Northern Ireland. [Accessed 1 February 2011]. Available at: http://www.qub.ac.uk/schools/CentreforArchaeologicalFieldworkCAF/Reports/DataStructureReports

McErlean, T., McConkey R. \& Forsythe, W. 2002. Strangford Lough, An Archaeological Survey of the Maritime Cultural Landscape. Belfast: Blackstaff Press.

McErlean, T., McNeary, R. \& Westley, K., 2011. Climate Change and Coastal Archaeology in Northern Ireland. Northern Ireland Environment Agency Coast, 7: 46-9.

McErlean, T. 2007. Archaeology of the Strangford Lough kelp industry in the Eighteenth- and early-Nineteenth centuries. Historical Archaeology, 41(3): 76-94.

McKenna, J., Carter, R.W.G. \& Bartlett, D. 1992. Coast erosion in Northern Ireland: - Part II cliffs and shore platforms. Irish Geography, 25:111-28.

McLaughlin, S. 2001. Assessment and development of a Coastal Vulnerability Index for Northern Ireland employing GIS techniques. PhD Thesis, University of Ulster 
McLaughlin, S. \& Cooper, J.A.G. 2010. A multi-scale coastal vulnerability index: A tool for coastal managers? Environmental Hazards 9:233-48.

McNeary, R. \& Westley, K. 2013. Climate change and Cultural Heritage. Report prepared for the Northern Ireland Environment Agency: Built Heritage Division. pp. 233

Murphy, P., Thackray, D. \& Wilson, E. 2009. Coastal Heritage and Climate Change in England: Assessing Threats and Priorities. Conservation and Management of Archaeological Sites, 11(1): 9-15.

Morgan, D., Pearson, S., Poulton, C. \& Evans, H. 2011. Intertidal Sediments and Geomorphology Characterisation Methodology Report. British Geological Survey Internal Report, OR/09/012. [accessed 16 February 2012]. Available at http://nora.nerc.ac.uk/16119/1/OR09012.pdf

Nitter, M., Elvestad, E. \& Selsing L. 2013. Maritime Site Protection and the Fetch Method: an example from Rogaland, Norway. International Journal of Nautical Archaeology, 42(1):87-102.

Reeder, L., Rick, T. \& Erlandson, J.M. 2012. Our disappearing past: a GIS analysis of the vulnerability of coastal archaeological resources in California's Santa Barbara Channel region. Journal of Coastal Conservation, 16(2):187-97.

Westley, K., Bell, T., Renouf, M. A. P. \& Tarasov, L. 2011. Impact assessment of current and future sea-level change on coastal archaeological resources - illustrated examples from Northern Newfoundland. Journal of Island and Coastal Archaeology, 6(3):351-74. 


\section{Figure Captions}

Figure 1. Location map of Northern Ireland showing breakup of the coastal zone into 10 regions for analysis purposes.

Figure 2. a) Province-wide distribution of oblique APs. Separation between individual APs is invisible at this scale, but the continuous coastal coverage is clear. b) Zoomed view of Magilligan Point showing separation of 100-200m between each AP. b) Oblique AP showing sandy beach and pier at Magilligan.

Figure 3. Simplified erosion summary for South Down. Place names are in italics. Black dots show locations of representative coastal erosion visible on the APs. A) Eroding scarp. B) and C) Unconsolidated cliff erosion. D) Low eroding scarp. The simpler erosion by photo layer is used as a proxy of erosion location because the digitized geomorphological/erosion polygons are difficult to see at this scale.

Figure 4. HER sites within $15 \mathrm{~m}$ and $150 \mathrm{~m}$ of mapped coastal erosion compared alongside all coastal HER sites in South Down. There is a noticeable difference between numbers of sites close to, and distant from mapped erosion; however, for those close to erosion, there is relatively little difference between the $15 \mathrm{~m}$ and $150 \mathrm{~m}$ buffers.

Figure 5. Mill Bay-Kilkeel area showing all coastal HER sites and those mapped within 15m/150m of erosion or seaward of the shoreline. Also shown are mapped areas of coastal erosion, in terms of erosion by AP, and also erosion by geomorphological landform, which is now visible at this scale. Note that $Y=$ erosion visible across $>50 \%$ individual $\mathrm{AP} /$ landform; Localized = erosion visible across $<50 \%$ individual AP/landform; $\mathrm{N}=$ No erosion visible.

Figure 6. Collapse of historic buildings (circled) at Derryoge due to cliff erosion.

Figure 7. Simplified erosion summary for Larne. Place names are in italics. Black dots show locations of representative coastal erosion visible on the APs. A) Eroding scarp behind beach. B) Possible marsh retreat. C) and D) Eroding scarp behind beach. The simpler erosion by photo layer is used as a proxy of erosion location because the digitized geomorphological/erosion polygons are difficult to see at this scale.

Figure 8. HER sites within $15 \mathrm{~m}$ and $150 \mathrm{~m}$ of mapped coastal erosion compared alongside all coastal HER sites in Larne.

Figure 9. Blackhead-Portmuck area showing all coastal HER sites and those mapped within 15/150m of erosion or seaward of the shoreline. Also shown are mapped areas of coastal erosion, in terms of erosion by AP, and also erosion by geomorphological landform, which is now visible at this scale. Note that $Y=$ erosion visible across $>50 \%$ individual $\mathrm{AP} /$ landform; Localized $=$ erosion visible across $<50 \%$ individual AP/landform; $\mathrm{N}=$ No erosion visible. Note that only the outer coast of Islandmagee has been examined at a local-scale.

Figure 10. Bar chart showing percentage of APs for each study area with visible erosion. Numbers above each bar represent the ranking of each study area.

Figure. 11. Bar charts showing A) numbers and B) percentages of coastal HER sites within $15 \mathrm{~m} / 150 \mathrm{~m}$ of areas with erosion or in the intertidal zone. Numbers above each bar represent the ranking of each study area. 


\section{Tables}

\begin{tabular}{|c|c|c|c|c|}
\hline Reference no. & Site type & Record & Observations & Risk level \\
\hline 03630:000:00 & Coastguard station & IHR & Protected by harbour & Low \\
\hline 03636:000:00 & $\begin{array}{l}\text { Coastguard station, lightkeepers } \\
\text { dwellings }\end{array}$ & IHR & Incorrect position (offshore channel) & Unknown \\
\hline 03637:000:00 & Beacon/lighthouse & IHR & Offshore beacon & Moderate \\
\hline 03638:000:00 & Beacon/lighthouse & IHR & Offshore beacon & Moderate \\
\hline 03641:000:00 & Lighthouse/lightkeeper's Housing & IHR & Protected by seawall & Low \\
\hline 03641:001:00 & Lighthouse & IHR & Protected by seawall & Low \\
\hline 03641:002:00 & Lightkeeper's Housing & IHR & Protected by seawall & Low \\
\hline 03642:000:00 & Haulbowline lighthouse & IHR & Offshore lighthouse & Moderate \\
\hline 07549:000:00 & Coastguard station & IHR & c. $50 \mathrm{~m}$ inland of defended shoreline & Low \\
\hline 11196:000:00 & Possible coastguard building & IHR & Protected by seawall & Low \\
\hline 440 & Bomb store & DHR & c. $80 \mathrm{~m}$ inland of eroding shoreline & Moderate \\
\hline DOW057:001 & Medieval motte (scheduled) & SMR & $\begin{array}{l}\text { c. } 60 \mathrm{~m} \text { inland of shoreline (not } \\
\text { presently eroding but could } \\
\text { potentially) }\end{array}$ & Moderate \\
\hline DOW057:009 & Possible mound & SMR & $\begin{array}{l}\text { c. } 110 m \text { inland from defended } \\
\text { shoreline }\end{array}$ & Low \\
\hline DOW057:010 & Late Medieval artillery fort & SMR & $\begin{array}{l}\text { On rock in Carlingford, reportedly } \\
\text { already storm damaged }\end{array}$ & High \\
\hline DOW057:011 & Shell midden (Mesolithic) & SMR & $\begin{array}{l}\text { Possibly within eroding section, or } \\
\text { even completely eroded }\end{array}$ & High \\
\hline DOW057:017 & Burials (poss medieval) & SMR & $\begin{array}{l}<5 \mathrm{~m} \text { from undefended shoreline (not } \\
\text { presently eroding but could } \\
\text { potentially) }\end{array}$ & High \\
\hline
\end{tabular}

Table 1. List of HER sites between Mill Bay and Kilkeel recorded as located seaward of the shoreline or within 150m of an eroding area and with risk levels assigned on the basis of individual site type and position. 


\begin{tabular}{|c|c|c|c|c|}
\hline Reference no & Site type & Record & Observations & Risk Level \\
\hline 06989:000:00 & Pier/harbour & IHR & Concrete structure, on coast & Moderate \\
\hline 06998:000:00 & Harbour & IHR & No visible remains? Bedrock cliffs & Moderate \\
\hline 07001:000:00 & Port & IHR & No visible remains? Bedrock cliffs & Moderate \\
\hline 07139:000:00 & Boat harbour (Hills Port) & IHR & No visible remains? Eroding shoreline & Moderate \\
\hline 07140:000:00 & Harbour & IHR & No visible remains? Eroding shoreline & Moderate \\
\hline 07141:000:00 & Boat port & IHR & No visible remains? Eroding shoreline & Moderate \\
\hline 07142:000:00 & Boat port & IHR & $\begin{array}{l}\text { No visible remains? (Shoreline not presently } \\
\text { eroding but could potentially) }\end{array}$ & Moderate \\
\hline 07143:000:00 & Boat port & IHR & No visible remains? Eroding shoreline & Moderate \\
\hline 07144:000:00 & $\begin{array}{l}\text { Boat harbour (Marchburn } \\
\text { port) }\end{array}$ & IHR & $\begin{array}{l}\text { Artificial channel visible (Shoreline not } \\
\text { presently eroding but could potentially) }\end{array}$ & High \\
\hline 07145:000:00 & $\begin{array}{l}\text { Boat harbour;port and } \\
\text { limestone quarry and limekiln } \\
\text { site }\end{array}$ & IHR & No visible remains? Eroding shoreline & Moderate \\
\hline 07147:000:00 & Boat port & IHR & $\begin{array}{l}\text { Possible artificial channel visible. Defended } \\
\text { shoreline }\end{array}$ & Moderate \\
\hline ANT041:002 & Mound (uncertain date) & SMR & $\begin{array}{l}\text { AP site, no visible remains. C. } 13 \mathrm{~m} \text { inland from } \\
\text { bedrock cliff }\end{array}$ & Low \\
\hline ANT041:013 & $\begin{array}{l}\text { Mound/rath? (uncertain } \\
\text { date) }\end{array}$ & SMR & $\begin{array}{l}\text { Reported as unlocated, but possible } \\
\text { corresponding feature is c. } 50 \mathrm{~m} \text { inland from } \\
\text { non-eroding shoreline }\end{array}$ & Low \\
\hline ANT041:023 & Fortification (uncertain date) & SMR & Wall around island, $<5 \mathrm{~m}$ from $\mathrm{HW}$, collapsing & High \\
\hline ANT041:024 & Well (uncertain date) & SMR & $\begin{array}{l}\text { Incorrect position (c. } 35 \mathrm{~m} \text { offshore). Possible } \\
\text { corresponding feature is } 30 \mathrm{~m} \text { inland of bedrock } \\
\text { cliff }\end{array}$ & Unknown \\
\hline ANT041:029 & $\begin{array}{l}\text { Two standing stones } \\
\text { (unlocated) (prehistoric) }\end{array}$ & SMR & Unlocated, position incorrect. & Unknown \\
\hline ANT047:029 & $\begin{array}{l}\text { Church (site of): Chapelfield } \\
\text { or the Eughs (uncertain date) }\end{array}$ & SMR & c. $20-30 \mathrm{~m}$ inland of eroding shoreline & Moderate \\
\hline ANT047:032 & Natural feature (boulder) & SMR & $\begin{array}{l}\text { At HW mark (shoreline not presently eroding } \\
\text { but could potentially) }\end{array}$ & Moderate \\
\hline ANT041:037 & $\begin{array}{l}\text { Findspot of skeleton } \\
\text { (C19th/18th) }\end{array}$ & SMR & Foot of bedrock cliff, c. $1 \mathrm{~m}$ above HW & Moderate \\
\hline
\end{tabular}

Table 2. List of HER sites between Blackhead and Portmuck recorded as located seaward of the shoreline or within $150 \mathrm{~m}$ of an eroding area and with risk levels assigned on the basis of site type and position. 


\begin{tabular}{|c|c|c|c|c|c|c|c|c|c|c|c|}
\hline $\begin{array}{l}\text { Area } \\
\text { no. }\end{array}$ & Area & $\begin{array}{l}\text { Coast } \\
\text { length } \\
(\mathrm{km}) \\
\end{array}$ & $\begin{array}{l}\text { No. } \\
\text { oblique } \\
\text { APs }\end{array}$ & $\begin{array}{l}\text { APs } \\
\text { per } \\
\mathrm{km}\end{array}$ & $\begin{array}{l}\text { No. } \\
\text { oblique } \\
\text { APs } \\
\text { showing } \\
\text { erosion }\end{array}$ & $\begin{array}{l}\% \\
\text { oblique } \\
\text { APs } \\
\text { with } \\
\text { erosion }\end{array}$ & $\begin{array}{l}\text { No. } \\
\text { coastal } \\
\text { HER } \\
\text { sites }\end{array}$ & $\begin{array}{l}\text { No. HER } \\
\text { sites } \\
\text { offshore/ } \\
<150 m \\
\text { from } \\
\text { erosion }\end{array}$ & $\begin{array}{l}\text { \% HER } \\
\text { sites } \\
\text { offshore/ } \\
<150 m \\
\text { from } \\
\text { erosion }\end{array}$ & $\begin{array}{l}\text { No. HER } \\
\text { sites } \\
\text { offshore/ } \\
<15 \mathrm{~m} \\
\text { from } \\
\text { erosion }\end{array}$ & $\begin{array}{l}\text { \% HER } \\
\text { sites } \\
\text { offshore/ } \\
<15 \mathrm{~m} \\
\text { from } \\
\text { erosion }\end{array}$ \\
\hline 1 & South Down & 85 & 480 & 5.6 & 69 & 14.4 & 49 & 22 & 44.9 & 18 & 36.7 \\
\hline 2 & SE Down & 82 & 656 & 8.0 & 71 & 10.8 & 80 & 36 & 45.0 & 31 & 38.8 \\
\hline 3 & $\begin{array}{l}\text { Strangford } \\
\text { Lough }\end{array}$ & 164 & 2058 & 12.5 & 240 & 11.7 & 689 & 638 & 92.6 & 561 & 81.4 \\
\hline 4 & Outer Ards & 80 & 1003 & 12.5 & 176 & 17.5 & 93 & 68 & 73.1 & 26 & 28.0 \\
\hline 5 & Belfast Lough & 88 & 531 & 6.0 & 46 & 8.7 & 183 & 44 & 24.0 & 35 & 19.1 \\
\hline 6 & Larne & 61 & 525 & 8.6 & 91 & 17.3 & 83 & 61 & 73.5 & 35 & 42.2 \\
\hline 7 & East Antrim & 61 & 483 & 7.9 & 89 & 18.4 & 104 & 55 & 52.9 & 20 & 19.2 \\
\hline 8 & North Coast & 104 & 639 & 6.1 & 110 & 17.2 & 151 & 84 & 55.6 & 39 & 25.8 \\
\hline 9 & Foyle & 85 & 598 & 7.0 & 171 & 28.6 & 48 & 34 & 70.8 & 23 & 47.9 \\
\hline \multirow[t]{2}{*}{10} & Rathlin & 32 & 184 & 5.8 & 26 & 14.1 & 236 & 119 & 50.4 & 91 & 38.6 \\
\hline & Total/Average & 842 & 7157 & 8.5 & 1089 & 15.2 & 1716 & 1161 & 67.7 & 879 & 51.2 \\
\hline
\end{tabular}

Table 3. Summary statistics for erosion and vulnerability assessment of coastal HER sites across Northern Ireland. 


\section{Figures}

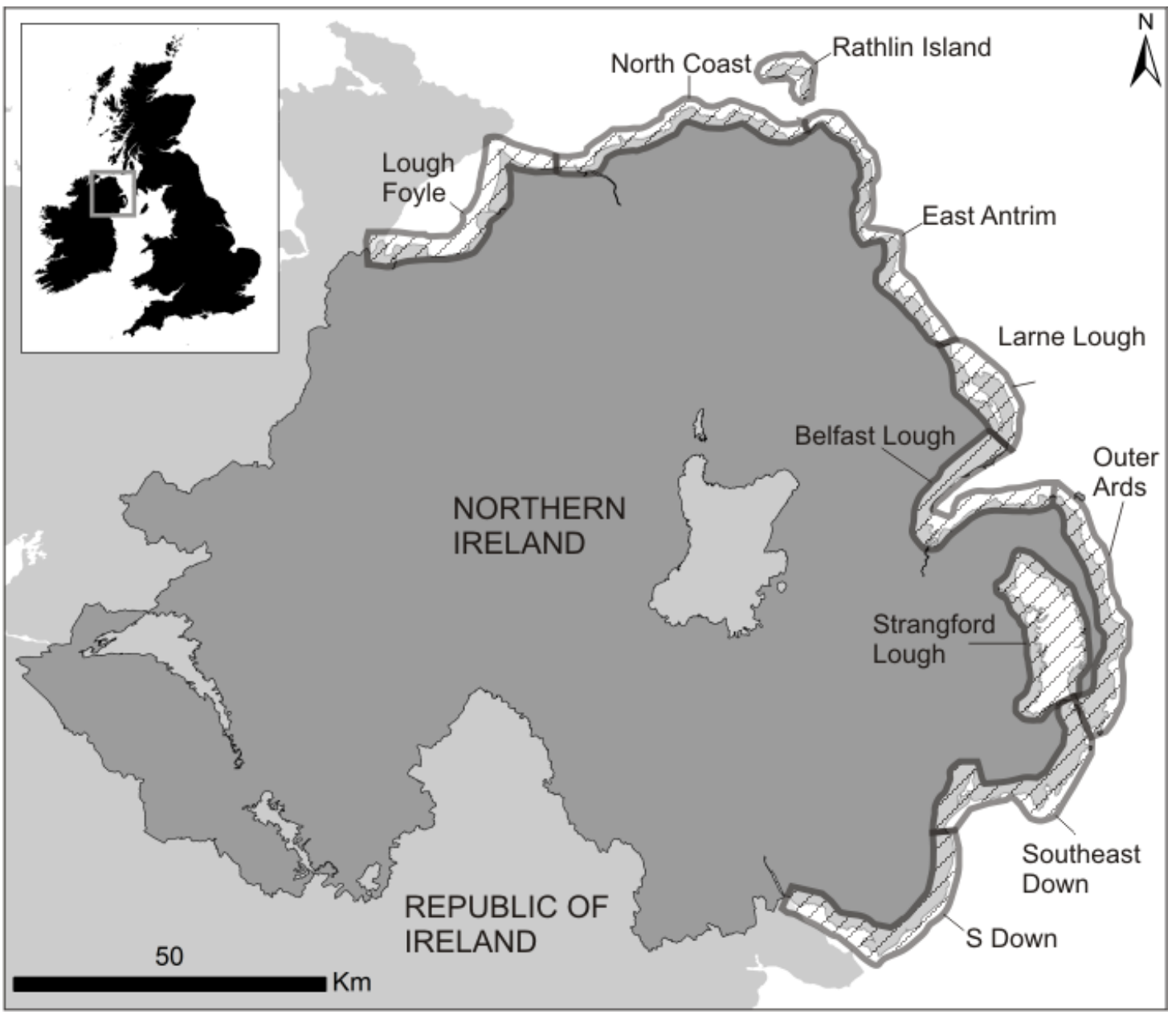

Figure 1. Location map of Northern Ireland showing breakup of the coastal zone into 10 regions for analysis purposes. 


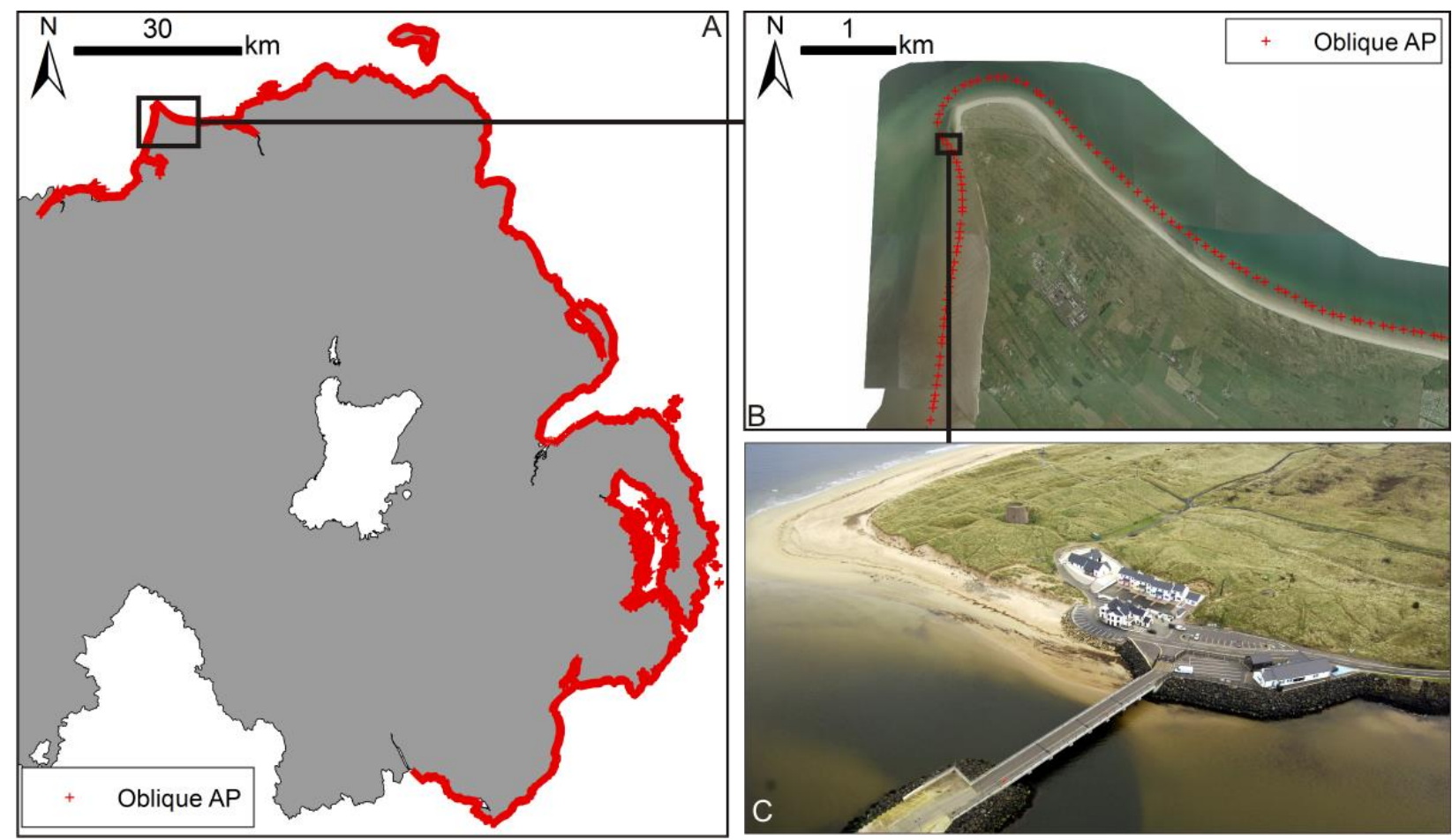

Figure 2. a) Province-wide distribution of oblique APs. Separation between individual APs is invisible at this scale, but the continuous coastal coverage is clear. b) Zoomed view of Magilligan Point showing separation of 100-200m between each AP. b) Oblique AP showing sandy beach and pier at Magilligan. 

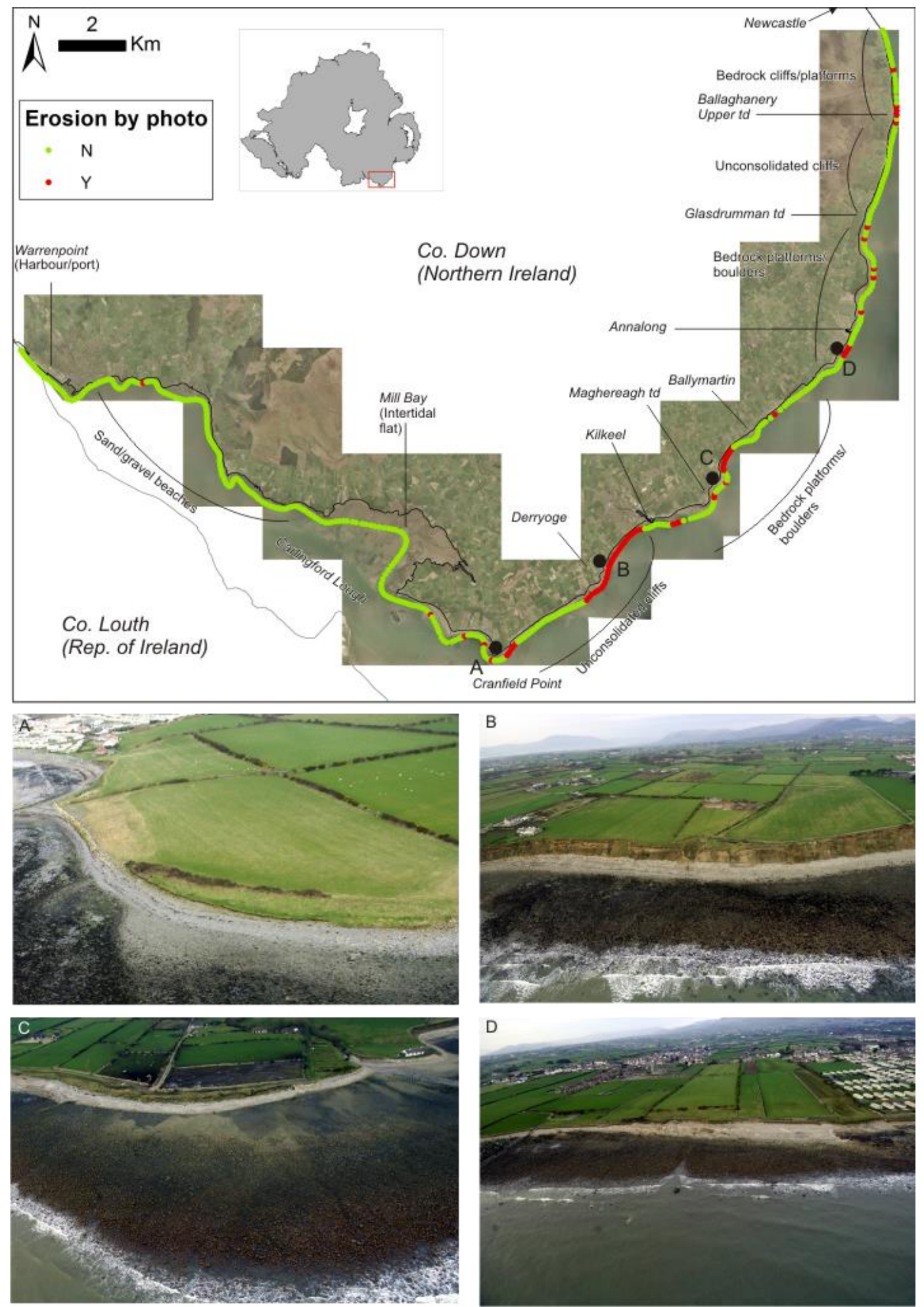

Figure 3. Simplified erosion summary for South Down. Place names are in italics. Black dots show locations of representative coastal erosion visible on the APs. A) Eroding scarp. B) and C) Unconsolidated cliff erosion. D) Low eroding scarp. The simpler erosion by photo layer is used as a proxy of erosion location because the digitized geomorphological/erosion polygons are difficult to see at this scale. 


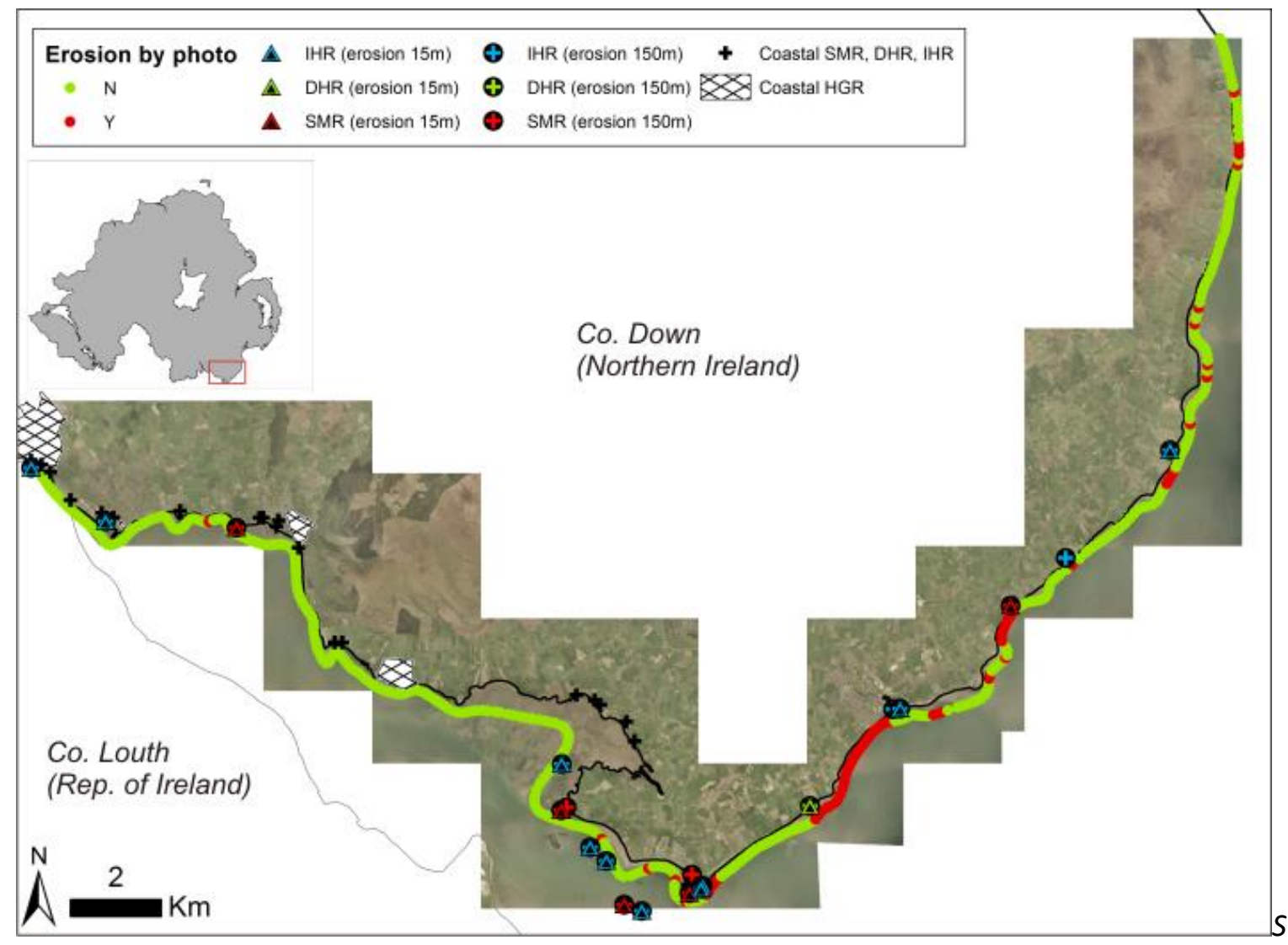

Figure 4. HER sites within $15 \mathrm{~m}$ and $150 \mathrm{~m}$ of mapped coastal erosion compared alongside all coastal HER sites in South Down. There is a noticeable difference between numbers of sites close to, and distant from mapped erosion; however, for those close to erosion, there is relatively little difference between the $15 \mathrm{~m}$ and $150 \mathrm{~m}$ buffers. 


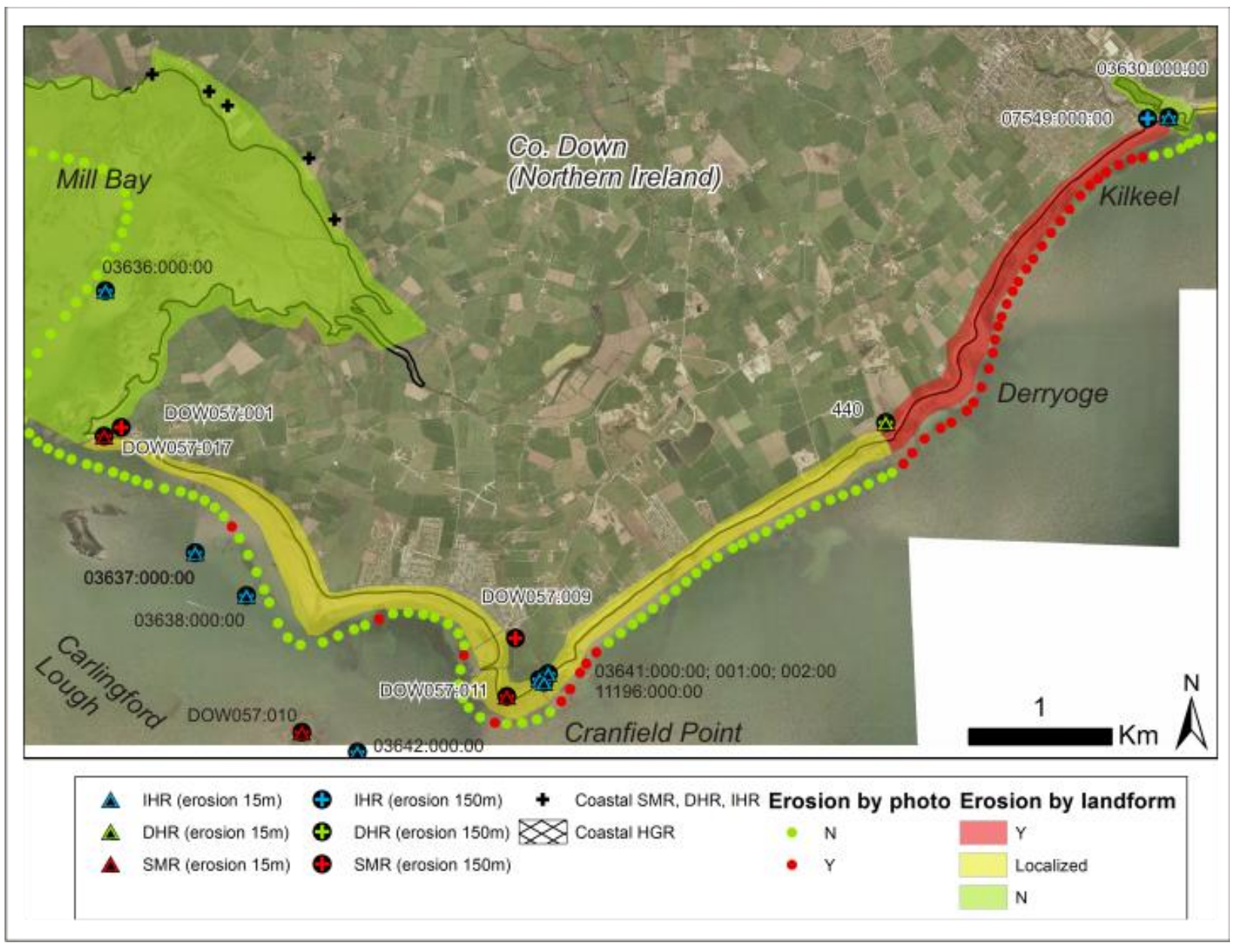

Figure 5. Mill Bay-Kilkeel area showing all coastal HER sites and those mapped within $15 \mathrm{~m} / 150 \mathrm{~m}$ of erosion or seaward of the shoreline. Also shown are mapped areas of coastal erosion, in terms of erosion by AP, and also erosion by geomorphological landform, which is now visible at this scale. Note that $Y=$ erosion visible across $>50 \%$ individual AP/landform; Localized $=$ erosion visible across $<50 \%$ individual AP/landform; $N=$ No erosion visible. 


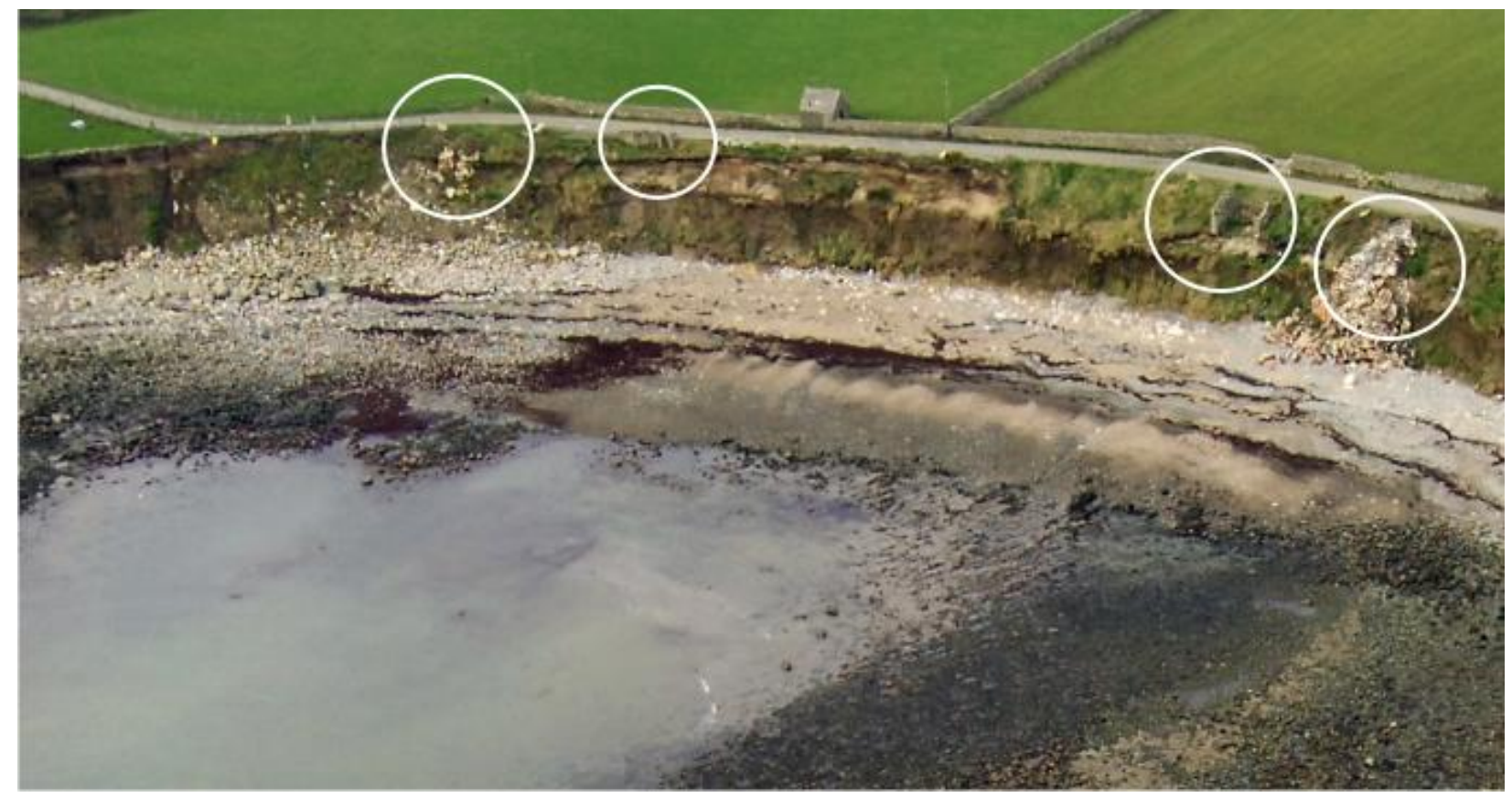

Figure 6. Collapse of historic buildings (circled) at Derryoge due to cliff erosion. 

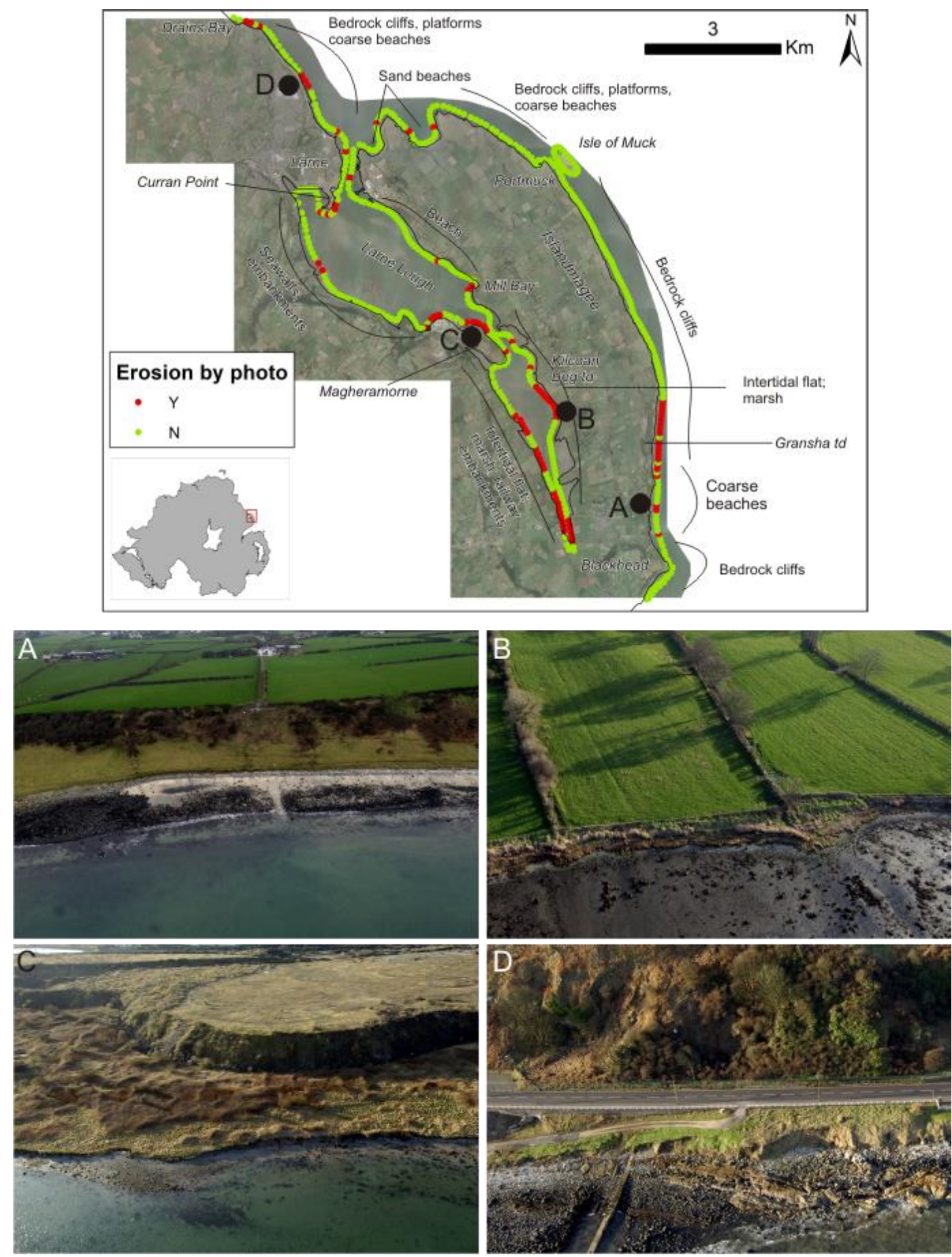

Figure 7. Simplified erosion summary for Larne. Place names are in italics. Black dots show locations of representative coastal erosion visible on the APs. A) Eroding scarp behind beach. B) Possible marsh retreat. C) and D) Eroding scarp behind beach. The simpler erosion by photo layer is used as a proxy of erosion location because the digitized geomorphological/erosion polygons are difficult to see at this scale. 


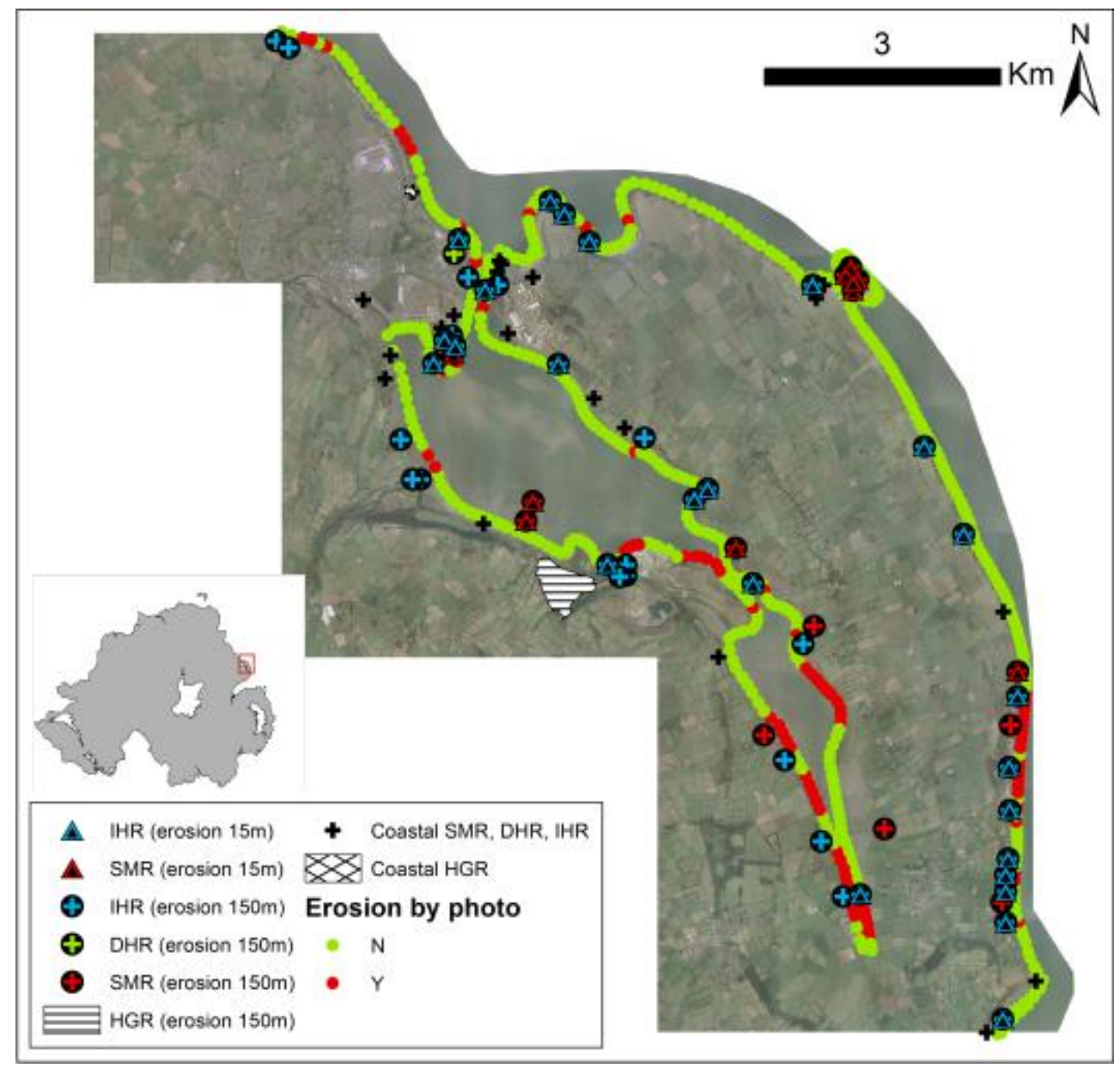

Figure 8. HER sites within $15 \mathrm{~m}$ and $150 \mathrm{~m}$ of mapped coastal erosion compared alongside all coastal HER sites in Larne. 


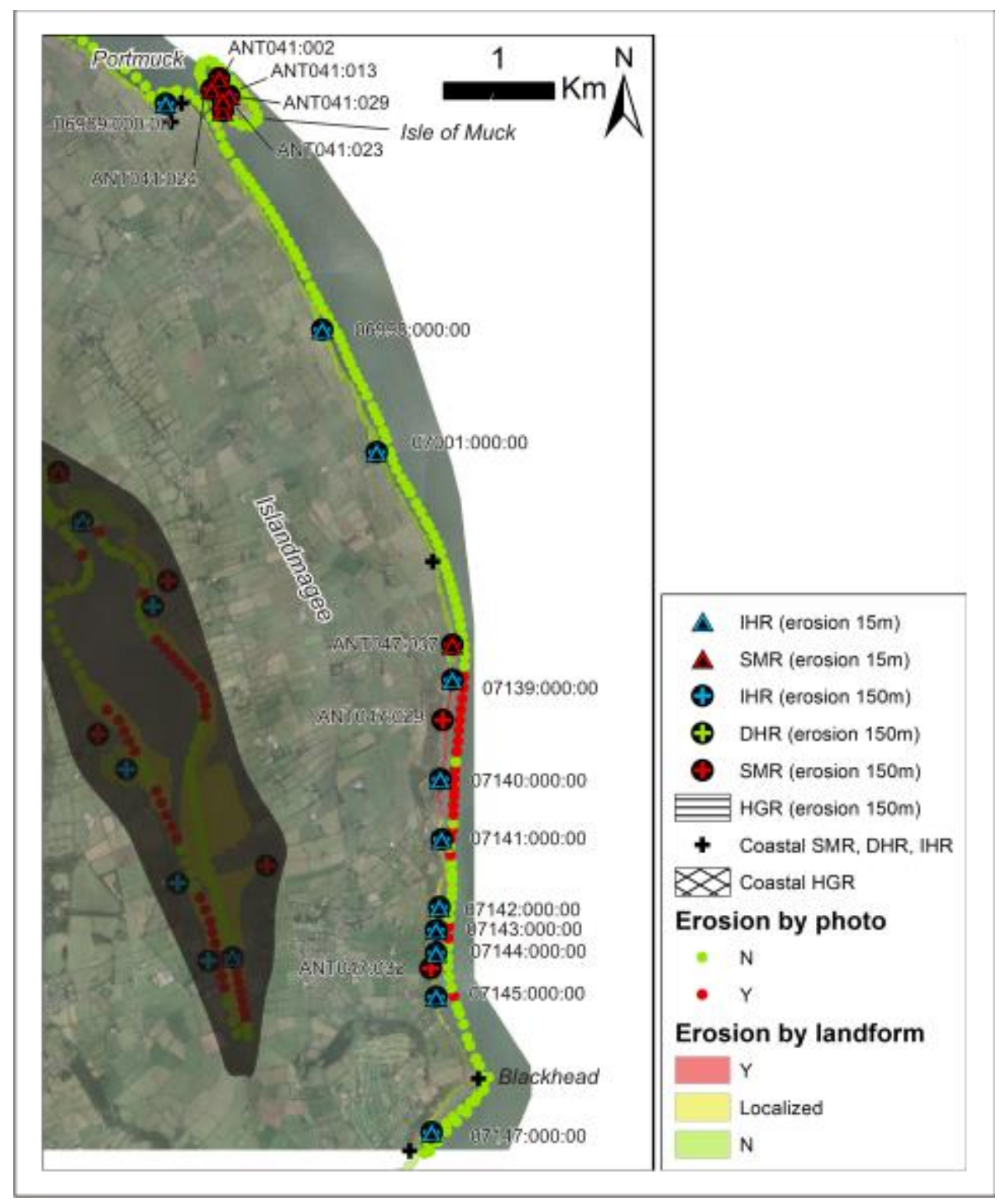

Figure 9. Blackhead-Portmuck area showing all coastal HER sites and those mapped within 15/150m of erosion or seaward of the shoreline. Also shown are mapped areas of coastal erosion, in terms of erosion by AP, and also erosion by geomorphological landform, which is now visible at this scale. Note that $Y=$ erosion visible across $>50 \%$ individual AP/landform; Localized = erosion visible across $<50 \%$ individual AP/landform; $N=$ No erosion visible. Note that only the outer coast of Islandmagee has been examined at a local-scale. 


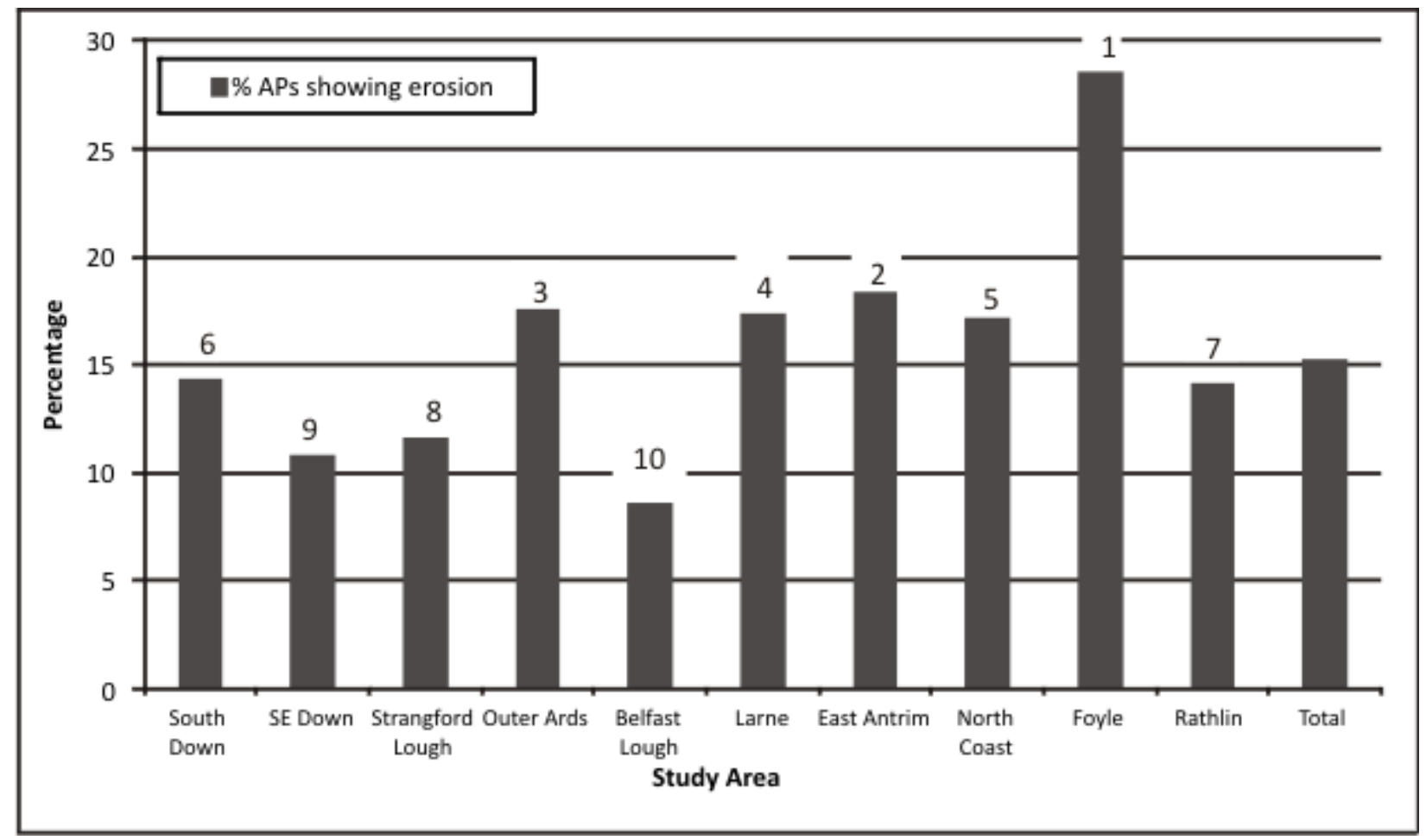

Figure 10. Bar chart showing percentage of APs for each study area with visible erosion. Numbers above each bar represent the ranking of each study area. 

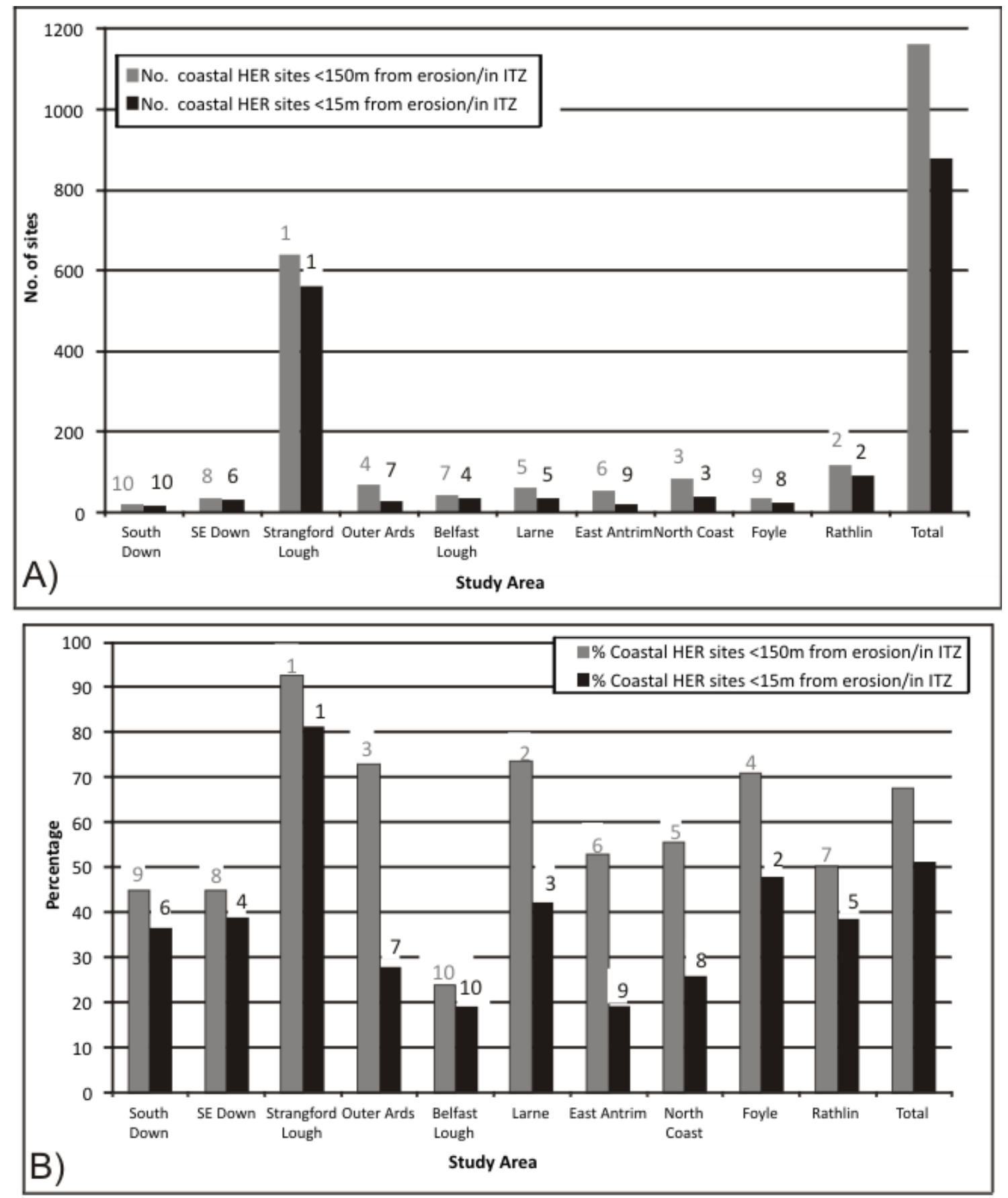

Figure. 11. Bar charts showing A) numbers and B) percentages of coastal HER sites within $15 \mathrm{~m} / 150 \mathrm{~m}$ of areas with erosion or in the intertidal zone. Numbers above each bar represent the ranking of each study area. 